\title{
Bacterial diseases in marine bivalves
}

Travers Marie-Agnès ${ }^{1}$, Miller Katharine ${ }^{2}$, Roque Ana ${ }^{3}$, Friedman Carolyn S. ${ }^{4}$

${ }^{1}$ Ifremer, Unité Santé Génétique Microbiologie des Mollusques (SG2M), Laboratoire de Génétique et Pathologie des Mollusques Marins (LGPMM), 17390 La Tremblade, France

2 Dept. of Biology, The College of William and Mary, Williamsburg, VA 23187, USA

${ }^{3}$ IRTA, Sant Carles de la Ràpita, 43540 Tarragona, Spain

${ }^{4}$ School of Aquatic and Fishery Sciences, University of Washington, Box 355020, Seattle, Washington 98195, USA

* Corresponding author : Marie-Agnès Travers, email address : $\underline{\text { marie.agnes.travers@ifremer.fr }}$

\section{Abstract :}

Bivalve aquaculture is seriously affected by many bacterial pathogens that cause high losses in hatcheries as well as in natural beds. A number of Vibrio species, but also members of the genera Nocardia and Roseovarius, are considered important pathogens in aquaculture. The present work provides an updated overview of main diseases and implicated bacterial species affecting bivalves. This review focuses on aetiological agents, their diversity and virulence factors, the diagnostic methods available as well as information on the dynamics of the host-parasite relationship.

\section{Graphical abstract :}

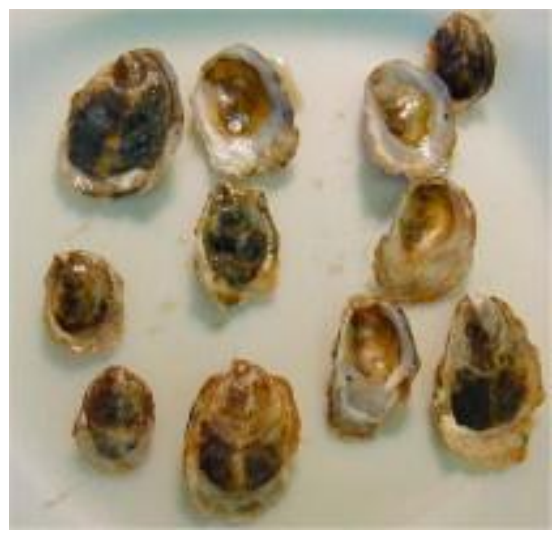




\section{Highlights}

- Focus on bacterial diseases affecting fisheries and aquaculture. Significant bacterial genera covered include Vibrio, Nocardia and Roseovarius. Host range, pathology, and available diagnostic methods for each disease are given. Classification of marine Vibrio spp. implicated in diseases remains difficult. Current emphasis on understanding virulence factors, disease onset and distribution.

Keywords : Vibrio, Nocardia, Roseovarius, Rickettsia, Pathogenesis, Diagnostic 


\section{Introduction}

Bacteria play important roles in the marine environment such as nutrient cycling, prey for other species, and influencing host health when in symbiotic relationships (ZilberRosenberg and Rosenberg, 2008). Parasitic or pathogenic relationships can govern population dynamics in both wild and farmed populations (Verschuere et al., 2000; Beaz-Hidalgo et al., 2010a; De Schryver and Vadstein, 2014). Bacterial pathogens have impacted marine molluscs for many years and a number of bacterial diseases have recently emerged or re-emerged. For example, Vibrio coralliilyticus (initially misidentified as $V$. tubiashii) re-emerged in northeast Pacific oyster hatcheries in 2005 where the bacterium caused catastrophic losses to Pacific oyster larvae (Elston et al., 2008). Roseovarius crassostreae, the causative agent of Roseovarius oyster disease (previously known as juvenile oyster disease), became the first identified pathogen in the abundant marine Roseobacter clade (Boettcher et al., 2005). Some pathogens, such as Nocardia crassostreae, expanded their known geographic range (into Europe; (Engelsma et al., 2008)) or jumped to a new host (e.g. N. crassostreae infections in Mytilus edulis; (Carella et al., 2013)).

Repeated episodes of mortality induced by pathogens constitute one of the main impediments to the culture of marine molluscs. Infectious diseases impact production and can cause high economic losses. Some taxa have been shown to affect all life stages of their hosts, including some of the most prolific pathogens in the genus Vibrio. These bacteria infect larval, juvenile and adult molluscs including oysters, mussels, abalones, clams, and scallops (Paillard et al., 2004; Beaz-Hidalgo et al., 2010a)). Other bacteria, such as the rickettsia that causes withering syndrome in abalone, are known to be pathogenic for specific hosts but are not associated with catastrophic losses (Friedman et al., 2002a; Friedman and Crosson, 2012; Crosson et al., 2014). The aim of this review is to provide an overview of bacterial taxa that infect marine bivalves, with a focus on groups that are considered most problematic. We provide a summary of aetiological agents, their diversity and virulence factors, diagnostic methods, host-parasite relationships, and future research needs.

In this review we define pathogenic organisms as those that can cause disease when they have successfully colonized a host. Bacterial taxa may contain species or strains within a species that vary from avirulent to virulent. Here we define virulence as a combination of infectivity (the ability to infect) and pathogenicity (the ability to cause disease and mortality in the host upon infection). Virulence results from the cooperation and sequential action of 
microbial components that can damage a susceptible host, and host responses, which together govern the host-microbe interaction (Casadevall and Pirofski, 2009). The dynamics of this interaction determine the outcome of the infection, including the severity of disease and level of mortality, which can be quantified to determine the level of virulence of a given taxon. It is important to recognize that virulence is not an independent microbial property and cannot be defined independently of a host (Casadevall and Pirofski, 2009).

\section{Vibriosis}

Bacteria within the genus Vibrio (Pacini 1854) are highly abundant in marine waters and have free-living and symbiotic, including pathogenic, life strategies (Thompson et al., 2004). Vibrio spp. are rod-shaped, gamma-proteobacteria and include many species that are pathogenic to both terrestrial and marine vertebrates and invertebrates (Paillard et al., 2004; Thompson et al., 2004). A total of 118 species are recognized in this genus, wherein classification and accurate identification are still problematic (Gevers et al., 2005; Hoffmann et al., 2012; Richards et al., 2014a). Bacteria belonging to the Splendidus clade, Harveyi clade or to the species $V$. aestuarianus, $V$. tubiashii, $V$. coralliilyticus, and $V$. tapetis are commonly reported in association with hatchery or field bivalve mortality events. Unfortunately, these bacteria are often misidentified at the species and/or strain level, and thereby cause confusion regarding specific host-pathogen dynamics.

\subsection{Vibrio splendidus-related:}

Etiological agent - Initial description. Bacteria belonging to Splendidus clade have been repeatedly described in relation to mortality events (Nicolas et al., 1996; Sugumar et al., 1998; Lambert et al., 1999; Lacoste et al., 2001; Waechter et al., 2002; Gay et al., 2004b; Kesarcodi-Watson et al., 2009a; Beaz-Hidalgo et al., 2010b; Saulnier et al., 2010).

Epidemiological studies of Vibrio splendidus-related strains associated with mollusc mortality outbreaks have demonstrated the importance of, and the high genetic diversity within, this polyphyletic group (Le Roux et al., 2002; Le Roux et al., 2004)). Such diversity has led to difficulties when classifying organisms within this particular clade (Figure 1), and many authors have grouped closely related bivalve pathogens as either $V$. splendidus (Nicolas et al., 
1996; Lacoste et al., 2001; Kesarcodi-Watson et al., 2009a), V. splendidus biovar II (Sugumar et al., 1998; Waechter et al., 2002; Gomez-Leon et al., 2005) or V. splendidus-related (Lambert et al., 1999; Gay et al., 2003; Saulnier et al., 2010) strains. Whether or not these bacteria represent a single species or multiple taxa is difficult to confirm with currently available diagnostic tools.

Etiological agent - Diversity. As mentioned above, classification within the Splendidus clade is constantly changing and species discrimination may be difficult among the 16 described member species: V. artaborum (Dieguez et al., 2011), V. atlanticus (Dieguez et al., 2011), V. celticus (Beaz-Hidalgo et al., 2010b), V. chagasii (Thompson et al., 2003c), V. crassostreae (Faury et al., 2004), V. cyclitrophicus, V. fortis (Thompson et al., 2003b), V. gallaecicus (Beaz-Hidalgo et al., 2009), V. gigantis (Le Roux et al., 2005), V. hemicentroti (Kim et al., 2013), V. kanaloae (Thompson et al., 2003c), V. lentus (Macian et al., 2001), V. pelagius (Macián et al., 2000), V. pomeroyi (Thompson et al., 2003c), V. splendidus (Reichalt et al., 1976), V. toranzoniae (Lasa et al., 2013), V. tasmaniensis (Thompson et al., 2003d). Groups of strains, belonging to the following species can be pathogenic to molluscs: $V$. celticus, V. crassostreae, V. cyclitrophicus, V.tasmaniensis and V. splendidus (Guisande et al., 2004; Prado et al., 2005; Saulnier et al., 2010; Vanhove et al., 2014). However, nonvirulent strains of these species can also be found.

Given the difficulty of identifying bacteria within the Splendidus clade, another and, possibly better, way to describe groups of strains implicated in mortality events may focus on a description of ecological populations, or communities (based on hsp60 sequences or concatenated sequences of $16 \mathrm{~S}$ rRNA, $g y r B$ and $p y r H$, but also on shared properties such as season of isolation, ecological habitat, virulence... (Hunt et al., 2008; Wendling et al., 2014). Recent work on a field-based disease study confirmed that a cluster of microdiverse Vibrio genotypes belonging to an ecologically cohesive population may drive oyster mortalities (Lemire et al., 2014). High-throughput experimental infection with a large collection of Vibrio collected after a field outbreak revealed that the majority of virulent strains (75\%) clustered into a subclass of an ecological population containing the $V$. crassostreae type strain (Lemire et al., 2014). Vibrio crassostreae was first isolated from diseased C. gigas (Faury et al., 2004), and the type strain LGP7T, as well as many other strains isolated from oysters, were demonstrated to be pathogenic for oysters (Gay et al., 2004a; Lemire et al., 2014). 
Many studies to determine disease causality are based on the assumption that the aetiologic agent is unique and present in moribund animals at high concentrations. However, it is now known that members of the Splendidus clade can cooperate in polymicrobial infections (Gay et al., 2004a; Gay et al., 2004b; Lemire et al., 2014). For example, interactions between virulent and avirulent strains (i.e. that do not induce any mortality, even when injected at $10^{6}$ bacteria/animal) can facilitate the disease induced by $V$. crassostreae (Lemire et al., 2014) or $V$. tasmaniensis (Gay et al., 2004b). In experiments using $V$. crassostreae J2-9 strain, injections of $10^{6}$ bacteria/animal or $4 \times 10^{4}$ bacteria/animal induced $90 \%$ and $0 \%$ mortality, respectively, whereas injection of $4 \times 10^{4}$ bacteria/animal in combination with the avirulent strain J2-20 induced 70\% mortality (Lemire et al., 2014).

Host - Bacteria belonging to Splendidus clade have been isolated in association with mortalities of the Pacific oyster in Japan (Sugumar et al., 1998) and in France (Lacoste et al., 2001; Waechter et al., 2002; Gay et al., 2004b; Saulnier et al., 2010), the European flat oyster, Ostrea edulis, in France (Thompson et al., 2003a), the Green shell mussel, Perna canaliculus, in New Zealand (Greenshell ${ }^{\mathrm{TM}}$ mussel (GSM) (Kesarcodi-Watson et al., 2009a)), the great Atlantic scallop Pecten maximus, in France (Nicolas et al., 1996; Lambert et al., 1999), and the carpeted shell clam Venerupis decussatus in Spain (Gomez-Leon et al., 2005). Experimental infection also demonstrated that some $V$. tasmaniensis strains can induce mortality in Venerupis rhomboides (Lago et al., 2009).

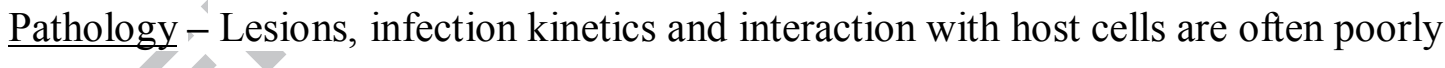
understood due to the diversity of bacteria belonging to the Splendidus clade and to the number of hosts and age classes they can infect. In addition, problems in differentiating among bacterial species can confound our understanding of the pathogenesis of vibriosis. For instance, the bacterium Vibrio kanaloae was isolated and characterized from O. edulis in France (Thompson et al., 2003a). Subsequently, virulence and pathological changes associated with injection of related strains were described in C. gigas (Gay et al., 2004b). Bacteria were found at the periphery of the adductor muscle and induced extensive lesions of the translucent portion of this tissue (Table 1). Unfortunately, no clear affiliation to $V$. kanaloae and $V$. pomeroyi species was possible despite the use of DNA-DNA hybridisation (Gay et al., 2004a).

A number of lesions were observed in diseased larvae and spat clams ( $V$. decussatus) during a mortality episode in which Vibrio splendidus biovar II and $V$. alginolyticus were 
isolated as predominant organisms (Gomez-Leon et al., 2005). Microscopic examination revealed the presence of bacilli in the velum and advanced infection with necrosis in larvae. Infected clams had pale digestive glands, likely due to a decrease in feeding activity upon infection. Bacteria were also detected along the mantle folds of experimentally infected spat. Disorganization of muscles fibers and a strong hemocytic infiltration, especially in the connective tissue, were also observed (Gomez-Leon et al., 2005) (Table 1). Velar infections were also observed in larval scallops, $P$. maximus, during a mortality episode when larvae were infected with Vibrio splendidus-related strains. Early signs of larval disease included velar damage with necrosis and detachment of velar cells (Table 1). Experimental infection using two of the Vibrio splendidus-related strains isolated during the larval scallop outbreak, confirmed their role as etiological agents. The observed larval disease was reproduced and mortalities were recorded between days 3 to 5 (Nicolas et al., 1996).

Virulence factors - In contrast to $V$. splendidus, the pathogenesis of Vibrio tasmaniensis is more defined. Virulence factors of $V$. tasmaniensis LGP32 have been described in-depth, including their role in vibriosis. $V$. tasmaniensis LGP32 was localized at the periphery of the adductor muscle after experimental infection and, like $V$. kanaloae (described above), induced extensive lesions within the translucent part of the muscle, without any associated infiltration (Gay et al., 2004b). The bacterial OmpU porin was shown to be a major effector of the interactions between $V$. tasmaniensis LGP32 and $C$. gigas (Duperthuy et al., 2010; Duperthuy et al., 2011). Specifically, OmpU was implicated in the virulence of the bacterium and its resistance to antimicrobials. By interacting with a $\beta$-integrin and an extracellular superoxide dismutase (SOD) acting as an opsonin, OmpU favors bacterial internalization into hemocytes where it can survive and avoid host responses. As observed in other vibrios, $V$. tasmaniensis can secrete toxic factors, such as the metalloprotease Vsm, into extracellular spaces (ECPs) (Le Roux et al., 2007; Binesse et al., 2008). The bacterium can also release outer membrane vesicles (OMVs), rich in hydrolases, both in the extracellular milieu and inside hemocytes. One of these hydrolases, the vesicular serine protease was found to be specifically secreted through OMVs, and to contribute to the virulence of LGP32 in experimental infections in oysters (Vanhove et al., 2014). Finally, a putative outer membrane protein, R5-7 (which has no known functional domain) is present in virulent strains of $\boldsymbol{V}$. crassostreae and was identified as a major factor responsible for its virulence (Lemire et al., 2014). 
Diagnosis/Detection - Bacteria belonging to the Splendidus clade can grow on Marine Agar or in Marine Broth at $20-22^{\circ} \mathrm{C}$ after $24-48$ hours. Thiocitrate bile salts medium (TCBS) or ChromAgar media can also be used for isolation (Figure 1), but due to the diversity of this group, molecular markers are needed for further identification. A qualitative qPCR method allows for the identification of bacterial isolates ascribed to the Splendidus clade (Ifremer, 2013), and some specific species tools for $V$.tasmaniensis, $V$. splendidus and $V$. neptunius are available (Lago et al., 2009) with a sensitivity limit corresponding to $2.4 \times 10^{2}$ to $2.8 \times 10^{4}$ cfu/g of tissue (Table 2). Most frequently, gene sequencing (16S rRNA, gyrB, hsp60, pyrH, etc.) and multilocus sequence analyses (MLSA) (Thompson et al., 2005) are used for isolate discrimination. However, as many species of this clade also contain non-virulent strains, diagnostic tools based on virulence factors are urgently needed.

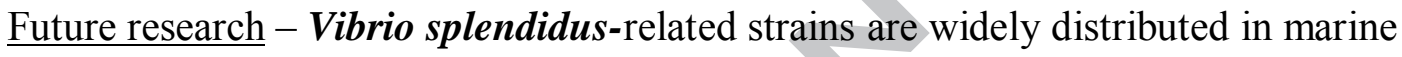
ecosystems (Farto et al., 1999) and are commonly detected even in the absence of disease (Tall et al., 2013). Pertinent diagnostic tools based on the identification of virulence factors and of ecologically coherent virulent groups of strains (i.e. "risky" populations of bacteria) (Lemire et al., 2014) are still needed.

\subsection{V. aestuarianus}

Etiological agent - Initial description. Vibrio aestuarianus was initially isolated from seawater, crab and sediment in 1983 in the USA (Tison and Seidler, 1983). Since its first characterization, two different sub-species have been described: V. aestuarianus subsp aestuarianus and V. aestuarianus subsp francensis (Garnier et al., 2008).

Etiological agent - Diversity. Despite the weak diversity within this species, recent genome studies of different $V$. aestuarianus strains revealed the existence of two distinct lineages with very low intra-clade and inter-clade diversity. These two lineages contain the majority of strains that are virulent for oysters. It is important to note that this study was based on strains mainly isolated during oyster mortality events and only a few environmental strains were analyzed. Perhaps not surprisingly, environmental strains revealed higher genetic diversity than pathogenic isolates (Goudenege et al., 2015). In challenge experiments, Vibrio aestuarianus subsp francensis induced mortality in Pacific oysters (Garnier et al., 2007; 
Garnier et al., 2008; Saulnier et al., 2010; Goudenege et al., 2015). The degree of virulence was variable in these trials: some strains induced high mortality rates ( $>50 \%$ mortality) whereas other strains exhibited low virulence or seemed avirulent ( $<15 \%$ mortality) (Garnier et al., 2008; Goudenege et al., 2015). Recently, Goudenège et al. (2015) suggested using the results obtained by challenge with various doses to define three categories: highly virulent strains ( $>50 \%$ mortality at $10^{2} \mathrm{CFU} /$ animal), non-virulent strains $\left(<50 \%\right.$ mortality at $10^{7}$ CFU/animal) and intermediate strains (strains pathogenic only at $10^{7} \mathrm{CFU} /$ animal), thus revealing phenotypic diversity within closed genotypes.

Host - Vibrio aestuarianus has been isolated from different marine species (Tison and Seidler, 1983). As detailed above, some strains have demonstrated virulence for the Pacific oyster (Garnier et al., 2007; Samain and McCombie, 2008). However, V. aestuarianus is moderately pathogenic for mussels Mytilus edulis in experimental challenges (Romero et al., 2014).

Pathology - Few data exist that describe the pathogenesis and histopathology of disease caused by $V$. aestuarianus in Pacific oysters (Table 1). V. aestuarianus can infect all ages of oysters and mortality reports associated with this bacterium have been observed in all oyster life stages (Garnier et al., 2007; Saulnier et al., 2010). However, juvenile and adult oysters seem to be more susceptible to the bacterium than are spat (i.e. young juvenile oysters). In experimental challenges, spat mortality resulted during cohabitation with infected oysters but the mortality rate was two times less for spat than for the other life stages (Dégremont et al., 2014).

Virulence factors - The virulence mechanisms of $V$. aestuarianus are not well characterized but several putative factors have been identified. The ECPs of a $V$. aestuarianus strain alter immune abilities of oysters by inducing a decrease of adhesion and phagocytosis capabilities of hemocytes and a deregulation of oxidative metabolism (Labreuche et al., 2006b). Infection with this strain also induced an inefficient reaction of the host cellular immune defenses (Labreuche et al., 2006a). One component of these ECPs was identified as a zinc-dependent metalloprotease called Vam (for $V$. aestuarianus metalloprotease), which was demonstrated to impair oyster hemocyte functions (Labreuche et al., 2010). Extracellular proteases are frequently described in Vibrio species (Nottage and Birkbeck, 1987; Lee et al., 1999; Lee et al., 2002) and probably play an important role in disease progression (Travis et al., 1995). Indeed, a relationship between the virulence of $V$. aestuarianus strains and their 
ability to produce metalloprotease-like proteins has been established (Saulnier et al., 2010). However, this metalloprotease gene is also present in avirulent strains, suggesting that although these strains possess the gene, it was not expressed under experimental conditions (Azandegbe et al., 2010). The expression of the Vam metalloprotease is regulated in part by growth stage dependent quorum sensing mechanisms (De Decker et al., 2013).

Metalloprotease expression seems to be also regulated by $\operatorname{var} S$, a gene coding for a signal transduction histidine protein kinase (Goudenège et al. 2015) similar to that demonstrated to control the expression of virulence genes in $V$. cholera (Jang et al., 2011).

Diagnosis/Detection - Vibrio aestuarianus is a cultivable halophilic bacterium, which grows well on Marine Agar or in Marine Broth at $20-22^{\circ} \mathrm{C}$ after 48 hours (Tison and Seidler, 1983; Garnier et al., 2008) (Figure 2A). Even if colonies on ChromAgar present a distinctive turquoise blue color (Figure $2 \mathrm{~B}$ ), biochemical tests are not sufficient to identify this species and molecular tests are necessary to confirm the diagnosis. A real time, quantitative PCR (qPCR) assay based on the dnaJ gene allows detection of Vibrio aestuarianus cells in pure culture, in seawater, and in oyster tissues (Saulnier et al., 2009). This tool was shown to detect all currently known strains of $V$. aestuarianus (as little as $1.6 \times 10^{2}$ cells $\mathrm{ml}^{-1}$ ) but could not differentiate between Vibrio aestuarianus subspecies (Table 2). Validation of this assay is currently underway.

Future research - Future research on genetic selection of oysters based on $V$. aestuarianus resistance and host immune response to this agent are now needed. Moreover, environmental factors influencing the distribution, abundance and infectivity of this bacterium is still unknown.

\subsection{V. tubiashii}

Etiological agent - Initial description. Bacillary necrosis was originally described on the east coast of America in diseased hard-shell clams (Tubiash et al., 1965; Tubiash et al., 1970), and in England and Spain in Pacific and flat oysters farms (Jeffries, 1982; Lodeiros et al., 1987). The etiological agent, V. tubiashii was isolated by Tubiash in 1965 (Tubiash et al., 1965). Due to its close taxonomic relationship with other Vibrio species such as $V$. coralliilyticus, $V$. tubiashii taxonomy has changed over time and led to misclassification of 
some strains. For instance, the ATCC19105 strain, first described by Tubiash et al. (1970) as $V$. anguillarum, was classified by Hada et al. (1984) as $V$. tubiashii, and recently reclassified as $V$. coralliilyticus as strains LMG 1095, RE 22 and RE 98, initially described as V. tubiashii and reclassified as $V$. coralliilyticus (Wilson et al., 2013; Richards et al., 2014a). However, this reclassification of some $V$. tubiashii (=V. coralliilyticus) strains does not change the fact that this bacterium is considered to be one of the potential pathogen of bivalves usually associated with major mortality events in shellfish hatcheries. In this section, we will refer to publications of $V$. tubiashii strains. Reclassified strains will be discussed in the $V$. coralliilyticus section.

It has been proposed that this bacterium re-emerged in North of America over the past decade (Estes et al., 2004; Elston et al., 2008) where it expanded its range to Pacific and Kumamoto oysters and geoduck clams (Elston et al., 2008). Despite the need for confirmation of the taxonomic identity of all isolates (some of the isolates were reclassified as $V$. coralliilyticus), the recent observation of this bacterium in association with upwelling events should provide insight into the physiology of $V$. tubiashii and/or $V$. coralliilyticus. $V$. tubiashii was recently described in France in diseased Pacific oysters and abalone (Travers et al., 2014).

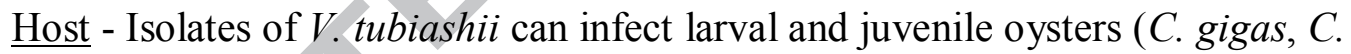
virginica, O. edulis) clams Mercenaria mercenaria (Guillard, 1959; Tubiash et al., 1965; Jeffries, 1982; Lodeiros et al., 1987), and juveniles of the mussel M. edulis (Asplund et al., 2014) and the gastropod Haliotis tuberculata (Travers et al., 2014). However, Koch's postulates were only demonstrated for some isolates that appeared virulent to larval and juvenile Pacific oysters in experimental challenges (Jeffries, 1982; Travers et al., 2014), and M. mercenaria larvae (Guillard, 1959).

Pathology - This disease is clinically characterized by a reduction in larval motility and an increase in soft-tissue necrosis (1970) (Figure 3, Table 1). During investigations on American V. tubiashii, Nottage et al. (1987) were the first to describe different proteases produced by five $V$. tubiashii strains. Subsequently, Kothary et al. (2001) showed that $V$. tubiashii could produce a toxin with cytotoxic and cytolytic properties. And recently, Mersni et al. (2014) demonstrated that the extracellular products of $07 / 118 \mathrm{~T} 2$, a representative strain of the group, inhibited the adhesion capacity and phagocytosis activity of $C$. gigas hemocytes. 
Virulence factors - Using larvae of C. gigas as an interaction model, V. tubiashii was shown to be virulent to larvae and to cause signs consistent with bacillary necrosis with a $\mathrm{LD}_{50}$ about $2.3 \times 10^{3} \mathrm{CFU} \mathrm{ml}^{-1}$ after $24 \mathrm{~h}$. Moreover, different fractions of the extracellular products secreted by this strain appeared toxic to larvae, suggesting that the pathological changes caused by the French $V$. tubiashii in $C$. gigas oysters is caused, in part, by a group of toxic factors (Mersni Achour et al., 2015). Considering the potential impact of this bacterium, draft genomes (Temperton et al., 2011) and a complete genome (Richards et al., 2014b) were recently sequenced and will enhance the exploration of potential virulence factors. The importance of cytolysin, outer membrane proteins and secreted metalloproteases has already been described for different $V$. tubiashii strains and constitute a bacterial virulence repertoire (Kothary et al., 2001; Delston et al., 2003; Beaubrun et al., 2008; Hasegawa et al., 2008; Hasegawa et al., 2009; Mersni Achour et al., 2014). As in many diseases, environmental conditions can influence the interaction of $V$. tubiashii with its host. $V$. tubiashii growth and virulence has been shown to be affected by temperature (Elston et al., 2008), nutrients, and particularly iron (Beaubrun et al., 2011). However, Asplund et al. (2014) also demonstrated an alteration of the $V$. tubiashii - Mytilus edulis interaction following long term acidification exposure, even though no obvious phenotypic changes in the host or bacterium (i.e. host immune response nor pathogen virulence) were observed. Another study demonstrated that although reduced seawater $\mathrm{pH}$ did not increase the virulence of this bacterium in larval Pacific oysters, the growth rate and total bacterial abundance were higher when grown in acidified marine waters - suggesting the potential for more common blooms of lethal levels of the bacterium for larvae (Dorfmeier, 2012). This work nicely demonstrated that environmental factors can influence interactions beyond host or pathogen individually.

Diagnosis/Detection - Both standard PCR (Sathyamoorthy et al., 2011) and qPCR tools (Gharaibeh et al., 2009; Travers et al., 2014) have been developed. In addition, detection with specific antibodies has been used (Gharaibeh et al., 2013) (Table 2). However, some of these tools are indeed not specific to differentiate $V$. tubiashii and $V$. coralliilyticus (Gharaibeh et al., 2009; Gharaibeh et al., 2013).

Future research - Even if the classification of many strains of $V$. tubiashii is not disputed, clarification of the literature on $V$. tubiashii is needed - especially regarding the geographical distribution and host specificity of this bacterium. Further, although several 
virulence factors have been described, their participation during pathogenesis, as well as the impact of the environment on the interactions with oysters, merits further study.

\subsection{V. coralliilyticus}

Etiological agent - Initial description. Initially described in association with diseased corals (Vezzulli et al., 2010), V. coralliilyticus was isolated from mortality episodes of Greenshell mussels (Kesarcodi-Watson et al., 2009a) and oysters (Hada et al., 1984), and was shown to be virulent to larval stages of those species (Kesarcodi-Watson et al., 2009b; Genard et al., 2013).

Etiological agent - Diversity. A high level of genetic polymorphism was observed comparing isolates from corals, bivalves and surrounding water. Two geographically distinct highly diverged clusters were detected within the zinc-metalloprotease gene, but their pathological signification is still unknown (Pollock et al., 2010b).

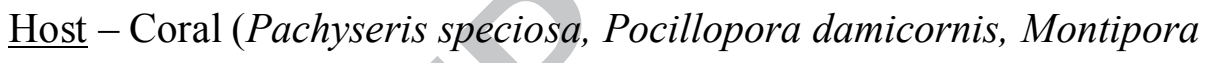
aequituberculata, Acropora cytherea, Pseudopterogorgia americana (Ben-Haim et al., 2003a) and oyster larvae (Kesarcodi-Watson et al., 2008).

Pathology - Gross signs of diseased larvae are quite common and can be confused with bacillary necrosis disease attributed to $V$. tubiashii. These include irregular movements, detachment of cilia, aggregation of bacteria around the velum and deterioration of soft tissues (Kesarcodi-Watson et al., 2009a) (Figure 3, Table 1). V. coralliilyticus exposure resulted in reduced feeding activity of oyster larvae, fatty acid remodeling of polar lipids, activation of defenses (antioxidant and immune defenses) (Genard et al., 2013) and larval bivalve mortality (Kesarcodi-Watson et al., 2009a; Kesarcodi-Watson et al., 2009b; Genard et al., 2013; Mersni Achour et al., 2015).

Virulence factors - Several virulence factors of $V$. coralliilyticus (some of which were identified as V. tubiashii) oyster-pathogenic strains have been described. Delston et al. (2003) demonstrated that $V$. coralliilyticus secretes a metalloprotease with high similarity with others proteases produced by pathogenic marine Vibrios. The $V$. coralliilyticus metalloprotease is 
considered to be primarily responsible for the toxicity of the bacterium's extracellular products to Pacific oyster larvae (Hasegawa et al., 2008; Hasegawa et al., 2009).

$V$. coralliilyticus is described as a temperature-dependent pathogen (Ben-Haim et al., 2003a; Ben-Haim et al., 2003b; Vezzulli et al., 2010; Kimes et al., 2012). Infection of the coral Pocillopora damicornis occurred predominantly at high seawater temperatures (27-29 C) (Ben-Haim et al., 2003a) and a single zinc-metalloprotease VcpA was identified as the key toxin in this disease process (Ben-Haim et al., 2003b; Sussman et al., 2008; de O Santos et al., 2011). Whole genome sequencing of the P1 strain, by de O Santos et al. (2011) shed light on the diverse repertoire of virulence factors of this bacterium by identifying 17 putative metalloproteases and a regulatory role of $\mathrm{VcpA}$. Analysis of the impact of a $v c p A$ deletion on proteins secreted by $V$. coralliilyticus $\mathrm{P} 1$ strain, indicates that VcpA zinc-metalloprotease might play a regulatory role on protein expression/secretion (chitinase, hemolysin/cytolysin VthA, aminopeptidases, hemolysin related protein RbmC, peptidases, Hcp protein). Many of those virulence factors were shown to be directly controlled by temperature. Putative virulence factors involved in motility, antibiotic resistance, hemolysis, cytotoxicity are upregulated in a $27^{\circ} \mathrm{C}$-proteome as compared to a $24^{\circ} \mathrm{C}$-proteome (Kimes et al., 2012). The complexity of virulence associated factors in this bacterium suggests that infection depends on the coordinated expression of several factors that act in concert to promote pathogenesis (de O Santos et al., 2011; Kimes et al., 2012).

Bacterial virulence is also dependent on the bacterium's environment, especially the presence of metal ions that may regulate type III secreted proteins (Schirrmeister et al., 2013)

Diagnosis/Detection - A real-time PCR diagnostic tool that can detect as little as 1 CFU per $\mathrm{ml}$ in seawater is published (Pollock et al., 2010a), as is a method allowing detection of virulent coral and molluscan pathogens, which targets a metalloprotease (one virulence factor) (Wilson et al., 2013). Additionally, an antibody-based and a qPCR tool to target $V$. tubiashii RE22, a strain reclassified as $V$. coralliilyticus, are also available, however their specificity should certainly be confirmed (Gharaibeh et al., 2009; Gharaibeh et al., 2013) (Table 2).

Future research - Comparison of isolates affecting bivalves and/or coral should help to characterize common and specific virulence mechanisms that $V$. coralliilyticus could employ, Further, research aimed at understanding the sequential and cooperative role of virulence 
factors such as metalloproteases and hemolysins (Hasegawa and Hase, 2009), should be advanced.

\subsection{Harveyi clade}

Etiological agent - The Harveyi clade is also known as the Vibrio core group (Sawabe et al., 2007). This clade includes the following species $V$. harveyi, $V$. campbellii, $V$. rotiferianus, $V$. parahaemolyticus, $V$. alginolyticus, $V$. natriegens, and V. mytili (Sawabe et al., 2007), which all share high phenotypic and genotypic homology (Cano-Gomez et al., 2009). Additional species have been added to this clade: $V$. azureus, $V$. owensii, $V$. communis and $V$. sagamiensis (Hoffmann et al., 2012). Members of this clade have been responsible for mortality outbreaks worldwide involving both fish and shellfish (Thompson et al., 2004; Saulnier et al., 2010; Ruwandeepika et al., 2012).

Host - Different bivalves can be affected by bacteria belonging to the Harveyi clade including C. gigas (Saulnier et al., 2010), V. decussatus (Gomez-Leon et al., 2005), Pinctada máxima (Pass et al., 1987 ) as well as the gastropods H. tuberculata (Nicolas et al., 2002) and Haliotis disersicolor supertexta (Liu et al., 2000; Cai et al., 2006a; Cai et al., 2006b).

Pathology - Most of the species of the Harveyi clade have been reported to induce vibriosis in molluscs. A study by Travers et al. (2008) reported on the pathogenesis of $V$. harveyi in the gastropod H. tuberculata and described the steps of infection: 1) adhesion and penetration; 2) incubation period without visible clinical signs, and 3) clinical expression of disease with associated mortalities. First steps of infection (gills adhesion and hemocyte alterations) were recently described and occurred in the first hours of contact (Cardinaud et al., 2014; Cardinaud et al., 2015).

Gomez Leon et al. (2007) reported two episodes of mortality of cultured carpet shell clams (Venerupis decussatus) associated with bacterial infections during 2001 and 2002 in a commercial hatchery located in Spain. Vibrio alginolyticus was isolated from moribund clam larvae that were obtained during the two separate events. However, in absence of experimental reproduction of the disease, its aetiology is not yet completely clear. The larval mortality rates for these events were 62 and 73\%, respectively. Under histopathological examination, clams showed a number of lesions including the presence of bacterial bacilli in 
the velum and advanced infection with necrosis in the clam tissue. A pale color of the digestive tract was observed in the affected larvae, probably caused by a decrease in feeding activity. Bacilli were also detected along the mantle folds of experimentally infected spat. Disorganization of muscles fibers and strong hemocytic infiltration, especially in the connective tissue, were also observed ( $\underline{\text { Table } 1)}$.

Virulence factors - Species of this clade produce several virulence factors reported elsewhere (see Ruwandeepika et al., 2012). Briefly, these, which vary among taxa, can be grouped in five types: (i) production of adhesion factors including adhesion to mucus, presence of pili, and chitinase; (ii) production of a variety of extracellular polysaccharides and biofilm formation derived from some of them, (iii) production of lytic proteins mainly hemolysins and proteases, (iv) siderophores and iron acquisition, (e.g.) vibrioferrin, and (v) Type III Secreting Systems, including TTSS1 and TTSS2.

Diagnosis/Detection - Many laboratories use phenotypic characterization for identification of Vibrios, and specific biochemical tests can be used following well known keys such as the one developed by Alsina and Blanch (1994) or using commercial kits such as API 20E (Biomerieux). However $V$. harveyi and its sister species $V$. campbellii and $V$. rotiferianus have nearly indistinguishable phenotypes, and misidentifications have occurred (Gauger and Gomez-Chiarri, 2002; Gomez-Gil et al., 2004). To differentiate among species within this clade, phenotypic characterization typically requires sequence analysis of the $16 \mathrm{~S}$ rRNA gene(Gomez-Leon et al., 2007). Use of molecular methods may combine higher discriminatory power and higher reproducibility than phenotypic tests, but they cannot be used as the sole diagnostic tools to confirm identity of pathogens from tissues (Burreson, 2008). In addition, for $V$. harveyi-related species, highly similar genomes and genome plasticity may also limit precise identification by molecular techniques in some cases (Thompson and Swings, 2006; Sawabe et al., 2007).

Discrimination among $V$. harveyi strains has been accomplished using the following molecular methods: DNA-DNA hybridization (DDH); amplified fragment length polymorphism (AFLP), repetitive extragenic palindromic elements PCR (REP-PCR) (GomezGil et al., 2004), random amplified polymorphic DNA (RAPD) (Pujalte et al., 2003; Hernandez and Olmos, 2004), ribotyping or ribosomal restriction fragment length polymorphism (RFLP) (Pujalte et al., 2003), amplified ribosomal DNA restriction analysis (ARDRA) (Kita-Tsukamoto et al., 2006), multilocus sequence analysis (MLSA) (Thompson 
et al., 2005; Thompson et al., 2007; Cano-Gomez et al., 2011), loop-mediated isothermal amplification (LAMP) (Cao et al., 2010), and TaqMan PCR to detect potentially virulent strains for H. tuberculata (Schikorski et al., 2014) (Table 2).

Future research: There is a need to clarify the role of a number of virulence factors in the disease process.

\subsection{V. tapetis}

Etiological agent - initial description. V. tapetis causes BRD (Brown Ring Disease) in the economically-important clam Venerupis (=Ruditapes) philippinarum. The first clam mortalities were reported in 1987 (Paillard and Maes, 1990; Flassch et al., 1992) in Brittany, and later on the South Atlantic French coast (1988-89), Italy (1990), Spain (1993), UK (1997-98), Tunisia (2000) and Norway (2003) (Paillard et al., 2004; Paillard et al., 2008). This disease is also found in South Korea (2003) and Japan (2004) (Park et al., 2008). The etiological agent associated with BRD, initially named Vibrio VP1, was later described as the novel species $V$. tapetis (Paillard et al., 1994; Borrego et al., 1996) and Koch's Postulates were satisfied (Paillard and Maes, 1990).

Etiological agent - diversity. Recently, two subspecies were described depending on the origin of the strains: $V$. tapetis subsp. tapetis and $V$. tapetis subsp. britannicus. The two subspecies are easily distinguishable by their capacity to produce acid from mannitol and arabinose and for their metabolization of citrate (Balboa and Romalde, 2013). Many strains have been isolated from molluscs and fish since the initial description of this disease (Castro et al., 1992; Maes and Paillard, 1992 ; Jensen et al., 2003; Reid et al., 2003; Matsuyama et al., 2010; Lopez et al., 2011). Interestingly the highest virulence recorded is still attributed to the first strain, CECT4600, isolated in Landéda in 1990 (Choquet et al., 2003) and contains a large conjugative plasmid pVT1 (Erauso et al., 2011). V. tapetis is highly polymorphic and displays a non-clonal population structure (Balboa et al., 2014).

Host - Different hosts can be infected by $V$. tapetis. Both $V$. philippinarum and $V$. decussatus the native European clam can become infected. However, while the former species is susceptible, $V$. decussatus is highly resistant to $\mathrm{BRD}$. The difference in resistance between these Venerupis species has been attributed to varying numbers of granular hemocytes and 
their phagocytic activity (Allam et al., 2006). Natural $V$. philippinarum clams populations from Galicia or Ireland also demonstrated differences in sensitivity to BRD (Drummond et al., 2007). Galician clams experienced significantly higher mortalities, BRD prevalence and $V$. tapetis levels than did Irish clams in the field. However, in laboratory trials Irish clams were also significantly affected by experimental challenge, as demonstrated by the development of BRD and an increase in $V$. tapetis levels in clam tissues. Taken together, these observations suggest that environmental factors play a key role in the susceptibility to infection and development of BRD, with more conducive environmental conditions in Galicia.

Some virulent strains of $V$. tapetis were also isolated from venus clam Venerupis aurea, common cockle Cerastoderma edule (Borrego et al., 1996; Paillard et al., 2006). Moreover, the reference strain CECT4600T can experimentally induce disease signs in cockles (Paul-Pont et al., 2010) and BRD signs were also detected in naturally infected populations, with a low prevalence (Lassale et al., 2007).

Pathology - V. tapetis enters the pallial cavity and adheres to the periostracal lamina. Subsequently the bacterium colonizes the edge of the mantle and periostracum, which induces the host to synthetize brown melanized organic protein matrix, conchiolin, whose composition is different from the shell matrix (Trinkler et al., 2011). This deposit progressively extends to internal surfaces of the valves. The presence and progression of conchiolin deposits is used to describe disease (7 steps), and repair (4 calcification steps or Shell Repair Stages, SRS were also described). The final step of disease coincides with bacterial proliferation in extrapalleal fluids and occasionally, the internal circulatory system, leading to septicemia and animal death (Allam et al., 2002) (Table 1).

V. tapetis can lead to animal both weakening and or death. Dead/moribund animals can be detected at the surface of sediments, with a brown ring conchiolin deposit on the internal face of the shell. Physiological parameters as growth rate (Flye-Sainte-Marie et al., 2009a), glycogen storage (Plana et al., 1996) are affected, reflecting the compromise between growth, energetic storage, defense against pathogen and tissues repairs.

Upon injection of bacteria into extrapalleal fluids, authors observed a rapid increase of total hemocytes concentration (THC) in the hemolymph, which was more or less stably maintained (Oubella et al., 1994; Oubella et al., 1996). This coincided with an increase of granulocytes (Oubella et al., 1994) associated with an increase in phagocytosis (Allam et al., 
2001). Recently, it has been demonstrated that levels of nitric oxide in the hemolymph increased in proportion with quantities of circulating $V$. tapetis (Jeffroy and Paillard, 2011). Bacteria can inhibit a hemocyte's adhesion capacity (Choquet et al., 2003) and lead to cytoskeleton disruption (Brulle et al., 2012). However, such hemolymph modifications were not observed in a field survey except for animals presenting advanced disease (more than stage 4) (Flye-Sainte-Marie et al., 2009b).

Virulence factors - To further investigate the repertoire of virulence factors among strains, proteomic approaches (Balboa et al., 2011a; Bermudez-Crespo et al., 2012; Madec et al., 2014) were employed. A lack of a published genome sequence limited the identification of potential virulence factors. A secretomic approach exploiting the unpublished sequence data, highlighted the absence of metalloproteases in the $V$. tapetis secreted fraction, and identified other proteins of interest, such as putative serine proteases and putative toxins; these finding require validation (Madec et al., 2014).

To date, the only $V$. tapetis virulence factor described is DjlA, an inner membrane cochaperone (dnaJ family involved in bacterial pathogenesis) that was implicated in the virulence phenotype of the bacterium. Functional mutation of this protein induced a loss of cytotoxic activity against hemocytes (Lakhal et al., 2008).

Diagnosis/Detection - In addition to specific signs of the disease process (brown ring disease stages and reparation stages), the presence of bacteria DNA can be revealed by PCR (Drummond et al., 2006; Paillard et al., 2006; Balboa et al., 2011b) and molecular fingerprinting of $V$. tapetis strains can be achieved by ERIC-PCR, REP-PCR and RAPD (Rodriguez et al., 2006) (Table 2).

$\underline{\text { Future research }}-\mathrm{A}$ better knowledge of the repertoire of virulence factors within this taxon, as well as their implication in the different steps of the disease should help to better understand the pathogenesis of this disease. Moreover, the pathological and ecological significance of the described subspecies should be confirmed.

3. Nocardiosis: Nocardia crassostreae (Nocardiosis in oysters) 
Etiological agent - Members of the genus Nocardia (Plylum Actinobacteria, Class Actinobacteria;(Stackebrandt et al., 1997)) are often members of soil saprophytic communities, including those within marine sediments, and can act as opportunistic pathogens (Friedman et al., 1991; Xu et al., 2009; Lee et al., 2014). Over 80 species have been described within this genus; many are found in marine environments (Olafsen et al., 1993; Euzeby, 2011). Nocardial infections in oysters were originally referred to as Focal Necrosis or Multiple Abscesses (Imai et al., 1965; Sinderman and Rosenfield, 1967; Imai et al., 1968; Koganezawa, 1974) and later renamed Fatal Inflammatory Bacteremia (Elston et al., 1987) and Pacific oyster nocardiosis, due to its clinical presentation and taxonomic placement, respectively. The disease is caused by the Gram-positive bacterium Nocardia crassostreae (Friedman et al., 1998) (Figure 4, Figure 5), which has a thermal optimum of $28^{\circ} \mathrm{C}$ but can grow at temperatures up to $30^{\circ} \mathrm{C}$ (Friedman and Hedrick, 1991; Friedman et al., 1998). Koch's postulates were experimentally satisfied using injection trials; no transmission of the bacterium was observed by co-habitation of inoculation of sediments with the bacterium (Friedman et al., 1991; Friedman and Hedrick, 1991). This bacterium has been identified in diseased oysters in Japan (Fujita et al., 1953; Fujita et al., 1955), North America (California and Washington state, U.S.A. and British Columbia, Canada; (Sinderman and Rosenfield, 1967; Lindsay, 1969; Katkansky and Warner, 1974; Glude, 1975; Elston, 1986; Friedman et al., 1991; Friedman et al., 1998), and Europe (The Netherlands; (Engelsma et al., 2008)).

$\underline{\text { Host }}$ - Although not identified as a new species of Nocardia until 1998 (Friedman et al., 1998), N. crassostreae was initially observed in the Pacific oyster C. gigas in association with host mortality. Although the bacterium was not always identified as the etiological agent of oyster mortality (Imai et al., 1965; Numachi and Oizumi, 1965; Perdue et al., 1981), N. crassostreae was demonstrated as a lethal pathogen causing up to $47 \%$ losses in laboratory trials (Friedman and Hedrick, 1991). The thermal range of the bacterium (up to $30^{\circ} \mathrm{C}$ ) may account for a lack of association with $N$. crassostreae infection and oyster mortality in Japan where researchers conducted a reciprocal translocation of oysters at temperatures above the thermal range for this bacterium $\left(>30-31^{\circ} \mathrm{C}\right.$; (Imai et al., 1965; Numachi and Oizumi, 1965; Tamate et al., 1965; Friedman et al., 1991; Friedman and Hedrick, 1991). This bacterium is also pathogenic to the European flat oyster Ostrea edulis in Washington state, Canada and Europe (Elston et al., 1987) and was suggested to be more susceptible to nocardial infections than the Pacific oyster in one study in Canada (Bower et al., 2005). Infections and mortality associated with nocardial infections occur during summer and fall months when water 
temperatures are warmer (usually over $20^{\circ} \mathrm{C}$ ) and has been linked to the phenomenon of summer mortality of oysters in some locations (Friedman et al., 1991; Friedman et al., 1998; Bower et al., 2005)

$\underline{\text { Pathology - Gross and clinical signs are fairly consistent among hosts. Oysters and }}$ mussels infected with $N$. crassostreae may show no clinical signs of infection or may develop flat to elevated yellow (occasionally green) lesions on the mantle, gill or within the adductor muscle (Elston et al., 1987; Friedman et al., 1991; Friedman and Hedrick, 1991; Engelsma et al., 2008; Carella et al., 2013) (igure 6). Microscopic examination reveals that lesions are composed of centrally located colonies of pleomorphic, branched Gram-positive bacteria surrounded by diffuse to focal accumulations of host hemocytes. In animals with heavy infections, focal lesions may coalesce into large multi-focal zones of bacteria and hemocytes (Elston et al., 1987; Friedman et al., 1991; Engelsma et al., 2008). The bacterium is commonly found within connective tissues and may be found within vascular sinuses or reproductive follicles. Interestingly, $N$. crassostreae rarely infects nephridium or digestive tubule epithelia (Friedman et al., 1991). In the Pacific oyster, colonies are primarily observed within connective tissues surrounding the gastrointestinal tract, reproductive follicles, and, to a lesser extent, within the mantle, digestive gland connective tissue, gills, and cardiac or adductor muscle (Elston et al., 1987; Friedman et al., 1991). While in European flat oysters, the bacterium is most commonly observed with vascular sinuses within connective tissues around the digestive tract and, to a lesser extent, in gonad, gills and mantle (Engelsma et al., 2008). In Mediterranean mussels, bacterial colonies were most frequently observed within connective tissues surrounding the digestive tract but were also found in the foot, mantle and gonads, including storage adipoglandular tissues (Carella et al., 2013) (Table 1).

Virulence Factors - No virulence factors have been characterized for N. crassostreae. However, several factors that influence the virulence of human-pathogenic nocardial species have been identified. The importance of superoxide dismutase (SOD) and catalase were demonstrated as important pathology determinants for N. asteroides (Beaman and Beaman, 1994). SOD was also identified from N. brasiliensis (Revol et al., 2006). Whole genome sequence analysis of $N$. brasiliensis revealed orthologs for virulence factors, especially genes involved in synthesis of bioactive compounds and in the synthesis and catabolism of lipids (Vera-Cabera et al., 2013) An association of the ability to inhibit phagosome-lysosome fusion and virulence has been well characterized in N. asteroides GUH-2 (Davis-Scibienski and 
Beaman, 1980). Whether or not these same virulence factors are important for N. crassostreae is not known.

Diagnosis/Detection - Presumptive diagnosis of infection with N. crassostreae can be made upon observation of gross clinical signs. Nocardial lesions may resemble those caused by Mikrocytos mackini, the protistan etiological agent of Denman Island disease, whose range in North America overlaps with that of N. crassostreae. However, N. crassostreae typically causes raised yellow to green lesions, while those caused by M. mackini are often flat and green, or concave with or without a greenish color; both pathogens may produce flat lesions that are green-yellow in color (Quayle, 1961; Elston et al., 1987; Farley et al., 1988; Friedman et al., 1991). Confirmatory diagnosis can be accomplished via culture of the bacterium using standard bacterial media from a lesion or from hemolymph samples coupled with morphological and biochemical tests and or and indirect fluorescent antibody test (IFAT), PCR, or qPCR (Friedman et al., 1998; Bower et al., 2005; Carella et al., 2013; Carrasco et al., 2014) (Table 2). Bacterial colonies are typically observed after 2-3 weeks of incubation at room temperature and are pale yellow, raised, wrinkled colonies with an irregular margin and lack aerial hyphae (Friedman et al., 1998). The bacterium does not grow above $30^{\circ} \mathrm{C}$ (Friedman et al., 1991; Friedman et al., 1998). The non-motile bacterium is beaded, branched and pleomorphic with a mycelium-like morphology that may fragment into irregular rods. $N$. crassostreae stains Gram-positive to Gram-variable, is acid fast using the Kinyon method and periodic acid Schiff base-positive (Friedman et al., 1998). Diagnostic stains and indirect antibody tests may also be employed using tissue sections of preserved animals (Friedman et al., 1998). Molecular assays (PCR, qPCR and in situ hybridization, and sequence analyses) or antibody-based assays can be used for bacterial identification on isolates and fresh or preserved tissue samples (Bower et al., 2005; Carella et al., 2013; Carrasco et al., 2014) (Table 2).

$\underline{\text { Future research }}$ - A better understanding of transmission dynamics and the role nocardiosis plays in bivalve health would benefit disease management and mariculture of affected species. In addition, understanding factors important in defining the virulence of this bacterium would aid our understanding of host-parasite relationships. Whole genome sequencing may reveal bacterial life styles as well as genes needed for pathogenesis. 
4. Roseovarius Oyster Disease (aka Juvenile Oyster Disease), Roseovarius crassostreae-

Etiological agent - The etiological agent of Roseovarius Oyster Disease (aka Juvenile Oyster Disease; JOD) was a previously undescribed species when first isolated from affected oysters (Boettcher et al., 1999). Subsequent analyses of the 16S rRNA gene placed the bacterium within the Roseobacter clade of the marine $\alpha$-Proteobacteria (Boettcher et al., 1999, 2000). At the time, marine roseobacters were known to be symbiotic with a variety of marine plants and invertebrates, but contained no known pathogenic species (Buchan et al., 2005). After phylogenetic and phenotypic characterization, the JOD-associated bacterium was designated Roseovarius crassostreae (Boettcher et al., 2000). Its etiological role was established based on its consistent association with JOD (Boettcher et al., 2000) and the satisfaction of Koch's postulates (i.e. reproduction of disease signs by experimental challenge) (Maloy et al., 2007b; Gomez-Leon et al., 2008). The presence of $R$. crassostreae was also documented during the initiation and development of a natural epizootic (Maloy et al., 2007b). In this study, the bacteria were first isolated coincident with the appearance of microscopic mantle lesions, and preceding the onset of outward signs and mortality. JOD was then renamed Roseovarius Oyster Disease (ROD) to avoid confusion with other diseases of juvenile oysters (Maloy et al., 2007b). To date, all isolates of $R$. crassostreae have originated from affected oysters but molecular surveys have also indicated a possible role for this species in various diseases of corals (Cooney et al., 2002; Pantos and Bythell, 2006; Godwin et al., 2012).

Host - ROD has only been documented in hatchery-produced Eastern oysters (Crassostrea virginica) raised in aquaculture (Bricelj et al., 1992; Davis and Barber, 1994; Ford and Tripp, 1996). There is no evidence that hatcheries are the source of infection, but rather, juvenile oysters appear to acquire pathogenic $R$. crassostreae from the ambient water at grow-out sites (Maloy et al., 2007a; Maloy et al., 2007b). Since 1988, ROD has affected nursery operations along the Northeast Atlantic coast of the United States, from Maine to New York (Bricelj et al., 1992; Davis and Barber, 1994; Ford and Borrero, 2001; Maloy et al., 2007b). Epizootics typically occur late in the summer at moderate salinities and temperatures (Bricelj et al., 1992; Davis and Barber, 1994; Barber et al., 1996). Affected oysters exhibit a drastic reduction in growth rates, fragile and uneven valve margins, cupping of the left valve, thin, watery tissues, and anomalous deposits of conchiolin on the inner shell surfaces (Bricelj 
et al., 1992; Davis and Barber, 1994) (Figure 7). Mortalities usually occur within 1-2 weeks of disease onset, and losses may exceed $95 \%$, especially among individuals $<25 \mathrm{~mm}$ in shell height (Bricelj et al., 1992; Davis and Barber, 1994; Barber et al., 1996; Boettcher et al., 1999). The overall manifestation is most similar to Brown Ring Disease (BRD) in Manila clams, caused by the bacterium Vibrio tapetis (Paillard et al., 1994).

Pathology - Specific virulence determinants and the exact mechanism(s) by which $R$. crassostreae causes mortality are still unclear. However, both whole cells and bacterial extracellular products from $R$. crassostreae have demonstrated toxicity to oyster hemocytes (Gomez-Leon et al., 2008). In addition, cultured $R$. crassostreae has been shown to produce tufts of polar fimbriae that may be involved in colonization of susceptible oysters (Boettcher et al., 2005). This hypothesis is supported by microscopic observation of $R$. crassostreae attached by their poles to the inner shell surfaces of affected individuals (Boardman et al., 2008). Once established, colonization by $R$. crassostreae progresses along the shell surfaces in a biofilm-like mode of growth (Boardman et al., 2008) which may help them evade host defenses. In fact, bacteriological and histological examination does not reveal any bacterial invasion of soft body tissues. Instead, generalized abnormalities such as mantle retraction, lesions, epithelial degradation and hemocytic infiltration into the pallial cavity are observed (Bricelj et al., 1992; Ford and Borrero, 2001; Maloy et al., 2007b). Presumably, these responses, as well as conchiolin deposition occurs as the host responds to, and attempts to contain, the infection to the inner valves. Unfortunately for the oyster, $R$. crassostreae also colonizes the newly synthesized conchiolin matrix (Boardman et al., 2008) (Figure 8), which in turn, induces additional conchiolin deposition and occasionally chronic infections in larger individuals (Maloy et al., 2007a). Among smaller oysters with more limited metabolic resources, death may result (at least in part) from starvation, perhaps as the result of a ciliostatic toxin. The dramatic reduction in filter-feeding observed in experimentally challenged oysters supports this hypothesis (Boettcher et al., 2000). Direct or indirect interference with feeding caused by $R$. crassostreae would also explain the reduction in growth rates observed in epizootics, and the emaciated appearance of tissues in affected individuals (Bricelj et al., 1992; Davis and Barber, 1994; Boettcher et al., 1999).

Diagnosis/Detection - The disease is most easily recognized among oysters $15-25 \mathrm{~mm}$ because they normally exhibit the full spectrum of ROD-signs in addition to significant mortality (Davis and Barber, 1994; Ford and Tripp, 1996). Mass mortalities of smaller oysters 
due to ROD can be misdiagnosed because the shells often lack the hallmark conchiolin deposits (Maloy et al., 2007a). Presumably this, and other host responses to infection, requires significant metabolic resources that are simply lacking in very small oysters (McDowell et al., 2014). At the other end of the spectrum, ROD among larger individuals (i.e. those $>25 \mathrm{~mm}$ ) may be missed because mortality rates among these populations are generally low (Davis and Barber, 1994). The inner shells of such animals, however, still contain layers of conchiolin indicative of a vigorous host response (Maloy et al., 2007a). While ROD-signs such as mantle abnormalities and hemocytic infiltration can be observed in oysters of any size using histological methods, these signs are not ROD-specific, nor do these methods target the sites of bacterial concentration (Boardman et al., 2008).

Regardless of the age/size of the affected oyster, $R$. crassostreae can be isolated in large numbers from the inner valve surfaces (Boardman et al., 2008). However, samples are very sensitive to proper handling, and recovery of $R$. crassostreae may be unsuccessful if processing is delayed too long ( $>48 \mathrm{~h}$ ) from the time of collection (Boettcher \& Maloy, unpub.). A specific seawater-based medium with tryptone and glycerol (SWT) (Boettcher and Ruby, 1990) is recommended for general culture purposes. Although marine agar (MA) is most widely for the isolation of marine heterotrophic bacteria, it does not support good growth of $R$. crassostreae. Colonies of $R$. crassostreae develop within 2-3 days on SWT agar and have a chalk-like texture (Boettcher et al., 1999). Most often, the colonies appear pinkishbeige, although greenish pigments have also been observed (Maloy et al., 2007a).

Confirmation of colony identity may be accomplished either via an antibody-agglutination test (Boardman, 2005) or by PCR amplification and sequencing of the 16S rRNA gene (Boettcher et al., 2005). A PCR-RFLP test based on the16S-23S rDNA internal transcribed spacer (ITS) region has also been developed that provides species and genotype-level identification of $R$. crassostreae (Maloy et al., 2005). It can be used on cultured cells or directly on material from suspected cases of ROD without the need for initial cultivation. Informative diversity in this $16 \mathrm{~S}-23 \mathrm{~S}$ ITS region has also proven useful for epizootiological studies of ROD in the northeastern United States (Maloy et al., 2007a) (Table 2).

$\underline{\text { Future research }}$ - Even before the etiology was established, a number of management strategies were developed to minimize the impact of ROD on commercial production. These include early deployment so that oysters reach the size refuge before seasonal occurrences of ROD in enzootic areas, maximizing water flow through culture systems, and the use of 
selected lines of oyster broodstock bred for resistance to ROD (Barber et al., 1998; Davis and Barber, 1999). While these approaches have been largely successful, the threat of ROD (especially for new growers) continues to limit the expansion of oyster aquaculture in the Northeast. Selective breeding efforts continue with the aim of producing resistant lines particularly suited to specific regions (Guo et al., 2003; Rawson and Feindel, 2012).

Efforts have also intensified to identify $R$. crassostreae virulence factors and mechanisms of host resistance. Researchers at the University of Rhode Island recently conducted transcriptome analysis to identify suites of oyster genes whose regulation is affected by exposure to $R$. crassostreae (McDowell et al., 2014). Transcripts corresponding to immune recognition and stress response proteins, as well as a serine protease inhibitor, were identified in challenged oysters. Further, challenged individuals from a resistant line differentially expressed a pro-inflammatory cytokine (IL-17), an immune regulator involved in nitric oxide production (arginase), and proteins involved in extracellular matrix repair. In contrast, susceptible oysters challenged with $R$. crassostreae differentially expressed metabolic enzymes. It is easy to envision how increased metabolic activity, coupled with feeding impairment following $R$. crassostreae colonization, would result in the rapid exhaustion of the animals' resources.

In addition to characterizing the potential role of $R$. crassostreae extracellular products (e.g. hemolysins, serine proteases, ciliostatic toxins, etc...) in pathogenesis, it is of great interest to determine what regulates the differential expression of fimbriae and flagella by these bacteria. For example, it may be that transition to a biofilm mode of growth in the oyster and/or the expression of virulence genes, may be controlled by quorum sensing systems as they are in many other bacterial species (Parsek and Greenberg, 2005). Indeed, quorum sensing homologues are widespread among members of the Roseobacter clade (Zan et al., 2014). The full genome sequence of $R$. crassostreae is nearly completed (D. Nelson, University of Rhode Island, pers. comm.) and when available, will greatly facilitate these studies.

\section{Rickettsia like organisms:}

Etiological agent -Rickettsia-like organisms (RLOs) are obligate intracellular, Gram negative, rod-shaped organisms (Fournier and Raoult, 2009). Coccoid forms are referred to as 
Chlamydia-like organisms, which have complex life histories, are rarely observed in marine bivalves and will not be discussed further in this review. Although terrestrial RLOs require a vector for transmission, marine RLOs are directly transmitted between hosts, typically via water-borne transmission (Friedman et al., 2002b; Fournier and Raoult, 2009). These bacteria may be found free within host cell cytoplasm but are more commonly observed within intracytoplasmic vacules (See review by Friedman and Crosson 2012). Like most RLOs, no RLOs infecting marine bivlaves have been cultivated on artificial media (Friedman et al., 2000; Fournier and Raoult, 2009) Friedman et al. 2000).

$\underline{\text { Host }}$-.Despite their importance as causative agents of severe mortality outbreaks in farmed aquatic species, little is known about their life cycle and their host range (Ferrantini et al., 2009). However, twenty -nine species of molluscs have been reported infected with RLOs (Delgado et al., 2007; Friedman and Crosson, 2012; Gollas-Galvan et al., 2013). The first detection of RLOs infecting a marine bivalve occurred in the 1970s and were observed in Mya arenaria (Harshbarger et al., 1977). It is important to note that not all infections reported have resulted in mortalities in affected host species.

Pathology - Rickettsia-like organisms usually cause asymptomatic infections (Carballal et al., 2001; Jones, 2007; Sabry et al., 2011). However in other cases, the presence of RLOs has been associated with high mortalities of farmed molluscs (Renault and Cochennec, 1994; Villalba et al., 1999; Wu and Pan, 1999; Wu et al., 2003; Suna and Wu, 2004; Delgado et al., 2007; Zhu et al., 2012). In the majoraity of these cases light microscopy was used to investigate the cause of mortality and identified the presence of intracellular colonies of bacteria. Histologically, RLO have been found in several species of bivalves within the epithelial cells of the mantle, digestive gland, gills and connective tissues. RLOs typically colonize cells of the digestive gland, gills or mantle and (Renault and Cochennec, 1994; Wu and Pan, 1999) (Table 1). In Callista chione, rickettsia-like colonies were detected in the gills of all the individuals examined (Delgado et al., 2007). Sun and Wu (2004) observed RLO in epithelial cells and connective tissues of the gill, mantle and digestive gland in most of the oysters, Crassostrea ariakensis, examined. Electron microscopic examination of infected tissues revealed that the RLOs were intracytoplasmic, usually with round form (when cut in cross section), dumbbell- shaped and occasionally rod-shaped; the bacterium ranged from approximately 0.58 to $1.20 \mu \mathrm{m}$ in size. The RLO had a trilaminar cell wall, electron-dense periplasmic ribosome zone and a DNA nucleoid. In addition, transverse binary 
fission of dividing RLOs was observed. Some enlarged cells contained hexagonal phage-like particles in the bacterial cytoplasm. RLOs have not been only detected inside the host cells; surprisingly, these bacteria have been reported to temporarily survive attached to the outside of gill cells of $C$. gigas, which may be a portal of entry for this bacterium (Azevedo and Villalba, 1991) (Table 1).

Other cases of mortality (up to 100\%, in May 2007) have been reported for cultured blood clam, Tegillarca granosa, occurred in the Yueqing Bay of China from 2005 to 2009, where an obligate intracellular prokaryote, designated as rickettsia-like organism (RLO), was frequently found in the moribund or dead blood clam samples during ultrastructural examination (Zhu et al., 2012). Mortality usually occurred between March and September and reached a peak in the spring and autumn seasons. The water temperatures at which the disease occurred ranged from 16 to $31^{\circ} \mathrm{C}$. When the mortalities occurred, moribund clams were usually anorexic and lethargic. The shells were either opened or closed incompletely and the mantle tissues were thin and easy to rupture. The gills appeared structurally disordered with the ends of the gill filaments ruptured or eroded. The internal organs appeared thin and pale. Under observation with the naked eye, small amounts of mucus were observed on the mantle, gills and visceral organs. Cytopathological examinations revealed extensive necrosis and destruction in the infected cells. The degree of tissue destruction was positively correlated to the number of RLO inclusions in the tissues, and the cytopathological effects were positively correlated to the number of intracellular RLOs (Zhu et al., 2012) ( $\underline{\text { Table 1). }}$ ).

Another mortality case reported to be caused by RLO occurred in farmed juvenile pearl oysters, Pinctada maxima (Wu et al., 2003). The peak of mortality rates, in general, occurred in 4-to 6-month old juvenile pearl oysters; mortality rates gradually declined with age (e.g. over 8 months old). Histological examination showed that peaks of RLO infections accompanied mortality peaks (Wu et al., 2003) (Table 1).

In Northern Spain a histopathological survey was performed to investigate the etiology of high mortality of the clam Venerupis rhomboides (Pennant) in exploited beds of the Ensenada de Riveira (Ria de Arousa, Galicia, NW Spain) (Villalba et al., 1999). According to prevalence, infection intensity and associated histopathological signs, a branchial rickettsialike organism was the only pathogen that could be tentatively blamed for the mortality. Spherical to elongated intracytoplasmic rickettsia-like colonies up to $25 \mu \mathrm{m}$ in length were observed at the base of gill filaments of the clams. Transmission electron microscopy allowed 
the identification of the microorganisms in the colonies as rickettsia-like. Individual bacteia measured about 0.5 to $0.8 \mathrm{pm}$ in diameter and up to $3 \mathrm{pm}$ in length. The infection process resulted in extreme hypertrophy and lysis of host epithelial cells Infection intensity was rated for each clam and comparison among high mortality-affected and non-affected populations and indicated that the branchial rickettsia-like infection as the probable cause of the clam deaths (Villalba et al., 1999).

Virulence factors - Despite the availability of complete genome sequencing and comparison between virulent and avirulent strains of terrestrial, human-pathogenic RLOs. The similarity of virulence factors identified for terrestrial RLO pathogens and marine representatives (Felsheim et al., 2009; Fournier et al., 2009), remains unknown.

Diagnosis/Detection - Most common diganostic technique for this group of pathogens is the detection of (typically) basophilic, intracellular colonies using light microscopy. Further characterisation is then done using TEM. Li and Wu (2004) compared three methods to purify RLO from mantle, gills and digestive glands from the scallop Argopecten irradians. They reported that the protocols based on ether treatment and sucrose density gradient centrifugation should not be applied to purify RLO used for immunity and transmission infection studies; these methods are appropriate exclusively for studies in which the bacterium does not have to be alive or physiologically viable, for instance, the study of nucleic acids. The extraction of total DNA followed by amplification of the r16S gene and sequencing has also been used with these preparation methods (Roux and Raoult, 1995). On the other hand, renografin density gradient centrifugation is a harmless isolation method for RLO; this method has been employed to isolate RLO from other molluscs and taxa (Wu et al., 2005; Zhu and $\mathrm{Wu}, 2008$ ); such technique allows making research on ultrastructural morphology of RLO and performing challenges in molluscs to evaluate their immune response against a RLO infection.

Future research - Our understanding of host-RLO dynamics in marine bivalve hosts is in its nascent stages. Characterizing the transmission, pathogenesis of RLO pathogens, virulence factors are needed as are validated diagnostic methods that allow differentiation among RLO taxa. The ability of in vitro or in vivo (cell lines) would greatly enhance our ability to study these organisms. 


\section{Concluding remarks}

On a global scale, outbreaks of disease have increased over last decades in the marine environment (Ward and Lafferty, 2004). Although the definitive causes for this increase are uncertain, ocean warming (Harvell et al., 2002) and marine pathogen emergence, reemergence or evolution (that can lead to colonization of new niches) appear to be important driving forces. For instance, bacteria of the Vibrio genus were shown to have increased in dominance within the plankton-associated bacterial community, in correlation with sea surface temperature, in the North Sea where an unprecedented increase in human infections related to these bacteria was recently reported (Vezzulli et al., 2011). In our changing environment, studies on the impact of predicted changes (temperature, salinity and acidification) on the evolution of bacteria, and their interactions, coupled with epidemiological model-based approaches should be encouraged (Altizer et al., 2013; Burge et al., 2014). Moreover, rapid identification of pathogens (virulent strains) should be an objective of future works, especially in marine aquaculture where movement of animals can be sources of pathogen introduction (Murray et al., 2012). With recent mass genomes sequencing (Le Roux et al., 2009; de O Santos et al., 2011; Vera-Cabera et al., 2013; Richards et al., 2014a; Richards et al., 2014b) and microbial genetic tools (Le Roux et al., 2007), we can expect more studies identifying and demonstrating the implication of virulence factors in pathogenesis that, in turn, can lead to new molecular tools for better epidemiological studies. Such tools should allow identification of previously isolated pathogens, and reclassification / precision of aetiological agents.

Finally, there is an increasing need for finding alternative ways to control microbial diseases in aquaculture. Such alternative approach may utilize bacteriolytic phages targeting causative agents, as bioagents for the treatment or prophylaxis of bacterial infectious disease (Oliveira et al., 2012). Initial approaches using phage-induced bacterial lysis of $V$. harveyi infecting shrimp have been published and could be extended on bivalves' pathogens (For review Oliveira et al., 2012). Cooperation among researchers may help expand our ability to understand and control bacterial diseases in marine hosts. 


\section{Figure legends}

Figure 1: Phenotypic diversity on (A) ChromAgar and (B) TCBS, of strains belonging to the large Splendidus clade and particularly to V. splendidus, V. gigantis, V. pomeroyi, $V$. crassostreae, V. tasmaniensis species (P. Haffner)

Figure 2: $V$. aestuarianus forms small colonies after $48 \mathrm{~h}$ at $22^{\circ} \mathrm{C}(\mathrm{A})$ on Zobell medium and (B) blue on ChromAgar (P. Haffner)

Figure 3: Detail of the non specific disease signs observed 24 hours post-infection in experimentally infected larvae with $V$. tubiashii (07/118 T2) or V. coralliilyticus (strain 06/210). Bar $=200 \mu \mathrm{m}$.

Figure 4: Colony of Nocardia crassostreae on Brain Heart Infusion agar. Bar $=10 \mu \mathrm{m}$. (Friedman et al; 1991; Paillard et al, 2004). Reprint with permission.

Figure 5: Gram-positive colonies of Nocardia crassostreae in connective tissues of a Pacific oyster. Brown and Brenn Gram stain. Bar $=10 \mu \mathrm{m}$. (Friedman et al; 1991; Paillard et al, 2004). Reprint with permission.

Figure 6: Pacific oyster with advanced nocardiosis as shown by the numerous pustule-like lesions throughout the mantle (arrows). Lesions are composed of N. crassostreae colonies and host hemocytes (Friedman et al; 1991). Reprint with permission.

Figure 7: ROD-affected juvenile Crassostrea virginica exhibiting fragile, uneven valve margins and conchiolin deposits on inner valve surfaces. (A. Maloy)

Figure 8: SEM images of an ROD-affected oyster. (A) Low magnification (30X) view of conchiolin deposit on inner shell valve. (B) High magnification $(16,000 \mathrm{X})$ view of the boxed region of panel A revealing bacteria attached to the conchiolin surface. 


\section{$\underline{\text { References }}$}

Allam, B., Ashton-Alcox, K. A., Ford, S. E., 2001. Haemocyte parameters associated with resistance to brown ring disease in Ruditapes spp. clams. Dev Comp Immunol. 25, 365-75.

Allam, B., Paillard, C., Auffret, M., Ford, S. E., 2006. Effects of the pathogenic Vibrio tapetis on defence factors of susceptible and non-susceptible bivalve species: II. Cellular and biochemical changes following in vivo challenge. Fish \& Shellfish Immunology. 20, 384-397.

Allam, B., Paillard, C., Ford, S. E., 2002. Pathogenicity of Vibrio tapetis, the etiological agent of brown ring disease in clams. Dis Aquat Organ. 48, 221-31.

Alsina, M., Blanch, A. R., 1994. A set of keys for biochemical identification of environmental Vibrio species. J Appl Bacteriol. 76, 79-85.

Altizer, S., Ostfeld, R. S., Johnson, P. T., Kutz, S., Harvell, C. D., 2013. Climate change and infectious diseases: from evidence to a predictive framework. Science. 341, 514-9.

Asplund, M. E., Baden, S. P., Russ, S., Ellis, R. P., Gong, N., Hernroth, B. E., 2014. Ocean acidification and host-pathogen interactions: blue mussels, Mytilus edulis, encountering Vibrio tubiashii. Environ Microbiol. 16, 1029-39.

Azandegbe, A., Garnier, M., Andrieux-Loyer, F., Kerouel, R., Philippon, X., Nicolas, J. L., 2010. Occurrence and seasonality of Vibrio aestuarianus in sediment and Crassostrea gigas haemolymph at two oyster farms in France. Diseases of Aquatic Organisms. 91, 213-221.

Azevedo, C., Villalba, A., 1991. Extracellular giant rickettsiae associated with bacteria in the gill of Crassostrea gigas (Mollusca, Bivalvia). J Invertebr Pathol. 58, 75-81.

Balboa, S., Bastardo, A., Romalde, J. L., 2014. Disentangling the Population Structure and Evolution of the Clam Pathogen Vibrio tapetis. Microbial Ecology. 67, 145-154.

Balboa, S., Bermudez-Crespo, J., Gianzo, C., Lopez, J. L., Romalde, J. L., 2011a. Proteomics and multilocus sequence analysis confirm intraspecific variability of Vibrio tapetis. Fems Microbiology Letters. 324, 80-87.

Balboa, S., Doce, A., Dieguez, A. L., Romalde, J. L., 2011b. Evaluation of different species-specific PCR protocols for the detection of Vibrio tapetis. Journal of Invertebrate Pathology. 108, 8591.

Balboa, S., Romalde, J. L., 2013. Multilocus sequence analysis of Vibrio tapetis, the causative agent of Brown Ring Disease: Description of Vibrio tapetis subsp britannicus subsp nov. Systematic and Applied Microbiology. 36, 183-187.

Barber, B. J., Carnegie, R. B., Davis, C. V., 1996. Effect of timing of seed deployment on growth and mortality of oysters, Crassostrea virginica, affected by Juvenile Oyster Disease (JOD). Journal of the World Aquaculture Society 27, 443-448.

Barber, B. J., Davis, C. V., Crosby, M. A., 1998. Cultured oysters, Crassostrea virginica, genetically selected for fast growth in the Damariscotta River, Maine, are resistant to mortality caused by Juvenile Oyster Disease (JOD). Journal of Shellfish Research. 17, 1171-1175.

Beaman, B. L., Beaman, L., 1994. Nocardia: host-parasite relationships. Annu. Rev. Clin. Microbiol. 7, 213-264.

Beaubrun, J. J., Gopinath, G., Kothary, M. H., Franco, A., Curtis, S. K., Eribo, B. E., et al., 2011. Influence of iron-chelated growth conditions on outer membrane protein production and virulence of Vibrio tubiashii. Food Microbiol. 28, 1409-13.

Beaubrun, J. J., Kothary, M. H., Curtis, S. K., Flores, N. C., Eribo, B. E., Tall, B. D., 2008. Isolation and characterization of Vibrio tubiashii outer membrane proteins and determination of a toxR homolog. Appl Environ Microbiol. 74, 907-11.

Beaz-Hidalgo, R., Balboa, S., Romalde, J. L., Figueras, M. J., 2010a. Diversity and pathogenecity of Vibrio species in cultured bivalve molluscs. Environmental Microbiology Reports. 2, 34-43.

Beaz-Hidalgo, R., Dieguez, A. L., Cleenwerck, I., Balboa, S., Doce, A., de Vos, P., et al., 2010 b. Vibrio celticus sp nov., a new Vibrio species belonging to the Splendidus clade with pathogenic potential for clams. Systematic and Applied Microbiology. 33, 311-315. 
Beaz-Hidalgo, R., Doce, A., Pascual, J., Toranzo, A. E., Romalde, J. L., 2009. Vibrio gallaecicus sp nov isolated from cultured clams in north-western Spain. Systematic and Applied Microbiology. 32, 111-117.

Ben-Haim, Y., Thompson, F. L., Thompson, C. C., Cnockaert, M. C., Hoste, B., Swings, J., et al., 2003a. Vibrio coralliilyticus sp. nov., a temperature-dependent pathogen of the coral Pocillopora damicornis. Int J Syst Evol Microbiol. 53, 309-15.

Ben-Haim, Y., Zicherman-Keren, M., Rosenberg, E., 2003b. Temperature-regulated bleaching and lysis of the coral Pocillopora damicornis by the novel pathogen Vibrio coralliilyticus. Appl Environ Microbiol. 69, 4236-42.

Bermudez-Crespo, J., Balboa, S., Alonso, J., Romalde, J. L., 2012. Two-dimensional proteome reference map of Vibrio tapetis, the aetiological agent of brown ring disease in clams. Journal of Applied Microbiology. 112, 853-864.

Binesse, J., Delsert, C., Saulnier, D., Champomier-Verges, M.-C., Zagorec, M., Munier-Lehmann, H., et al., 2008. Metalloprotease Vsm Is the Major Determinant of Toxicity for Extracellular Products of Vibrio splendidus. Appl. Environ. Microbiol. 74, 7108-7117.

Boardman, C., 2005. Host-pathogen interactions between eastern oysters (Crassostrea virginica) and the bacterial agent of juvenile oyster disease (Roseovarius crassostreae). MS Thesis, University of Maine

Boardman, C. L., Maloy, A. P., Boettcher, K. J., 2008. Localization of the bacterial agent of juvenile oyster disease (Roseovarius crassostreae) within affected eastern oysters (Crassostrea virginica). J Invertebr Pathol. 97, 150-8.

Boettcher, K. J., Barber, B. J., Singer, J. T., 1999. Use of antibacterial agents To elucidate the etiology of juvenile oyster disease (JOD) in Crassostrea virginica and numerical dominance of an alpha-proteobacterium in JOD-affected animals. Appl Environ Microbiol. 65, 2534-9.

Boettcher, K. J., Barber, B. J., Singer, J. T., 2000. Additional evidence that juvenile oyster disease is caused by a member of the Roseobacter group and colonization of nonaffected animals by Stappia stellulata-like strains. Appl Environ Microbiol. 66, 3924-30.

Boettcher, K. J., Geaghan, K. K., Maloy, A. P., Barber, B. J., 2005. Roseovarius crassostreae sp. nov., a member of the Roseobacter clade and the apparent cause of juvenile oyster disease (JOD) in cultured Eastern oysters. Int J Syst Evol Microbiol. 55, 1531-7.

Boettcher, K. J., Ruby, E. G., 1990. Depressed light emission by symbiotic Vibrio fischeri of the sepiolid squid Euprymna scolopes. J Bacteriol. 172, 3701-3706.

Borrego, J. J., Luque, A., Castro, D., Santamaria, J. A., Martinez-Manzanares, E., 1996. Virulence factors of Vibrio P1, the causative agent of brown ring disease in the Manila clam, Ruditapes philippinarum. Aquatic Living Resources. 9, 125-136.

Bower, S. M., Goh, B., Meyer, G. R., Carnegie, R. B., Gee, A., Epizootiology and detection of nocardiosiis in oysters. In: P. Walker, et al., Eds.), Diseases in Asian Aquaculture V. Asian Fisheries Society, Fish Health Section, Manila, 2005, pp. 249-262.

Bricelj, V. M., Ford, S. E., Borrero, F. J., Perkins, F. O., Rivara, G., Hillman, R. E., et al., 1992. Unexplained mortalities of hatchery-reared, juvenile oysters, Crassostrea virginica (Gmelin). . Journal of Shellfish Research 11, 331-347.

Brulle, F., Jeffroy, F., Madec, S., Nicolas, J. L., Paillard, C., 2012. Transcriptomic analysis of Ruditapes philippinarum hemocytes reveals cytoskeleton disruption after in vitro Vibrio tapetis challenge. Dev Comp Immunol. 38, 368-76.

Buchan, A., González, J. M., Moran, M. A., 2005. Overview of the Marine Roseobacter Lineage. App1 Environ Microbiol. 71, 5665-5677.

Burge, C. A., Mark Eakin, C., Friedman, C. S., Froelich, B., Hershberger, P. K., Hofmann, E. E., et al., 2014. Climate change influences on marine infectious diseases: implications for management and society. Ann Rev Mar Sci. 6, 249-77.

Burreson, E., 2008. Misuse of PCR assay for diagnosis of mollusc protistan infections. Diseases of Aquatic Organism. 80, 81-83.

Cai, J., Han, Y., Wang, Z., 2006a. Isolation of Vibrio parahaemolyticus from abalone (Haliotis diversicolor supertexta L.) postlarvae associated with mass mortalities. Aquaculture. 257, 161-166. 
Cai, J., Song, Z., Li, C., Zhou, J., 2006b. Isolation and characterisation of pathogenic Vibrio alginolyticus from diseased postlarval abalone Haliotis diversicolor supertexta (lischke) Aquaculture Research. 37, 1222-1226.

Cano-Gomez, A., Bourne, D. G., Hall, M. R., Owens, L., Hoj, L., 2009. Molecular identification typing and tracking of Vibrio harveyi in aquaculture systems: Current methods and future prospects. . Aquaculture. 287, 1-10.

Cano-Gomez, A., Hoj, L., Owen, L., Andreakis, N., 2011. Multilocus sequence analysis provides basis for fast and reliable identification of Vibrio harveyi-related species and reveals previous misidentification of important marine pathogens. Syst Appl Microbiol. 34, 561-565.

Cao, Y. T., Wu, Z. H., Jian, J. C., Lu, Y. S., 2010. Evaluation of a loop-mediated isothermal amplification method for the rapid detection of Vibrio harveyi in cultured marine shellfish. Lett Appl Microbiol. 51, 24-9.

Carballal, M. J., Iglesias, D., Santamarina, J., Ferro-Soto, B., Villalba, A., 2001. Parasites and Pathologic Conditions of the Cockle Cerastoderma edule Populations of the Coast of Galicia (NW Spain). Journal of Invertebrate Pathology. 78, 87-97.

Cardinaud, M., Barbou, A., Capitaine, C., Bidault, A., Dujon, A. M., Moraga, D., et al., 2014. Vibrio harveyi Adheres to and Penetrates Tissues of the European Abalone Haliotis tuberculata within the First Hours of Contact. Applied and environmental microbiology. 80, 6328-6333.

Cardinaud, M., Dheilly, N. M., Huchette, S., Moraga, D., Paillard, C., 2015. The early stages of the immune response of the European abalone Haliotis tuberculata to a Vibrio harveyi infection. Developmental \& Comparative Immunology. 51, 287-297.

Carella, F., Carrasco, N., Andree, K. B., Lacuesta, B., Furones, D., De Vico, G., 2013. Nocardiosis in Mediterranean bivalves: first detection of Nocardia crassostreae in a new host Mytilus galloprovincialis and in Ostrea edulis from the Gulf of Naples (Italy). Journal of Invertabrate Pathology. 114, 324-328.

Carrasco, N., Roozenburg, I., Voorbergen-Laarman, M., Itoh, N., Engelsma, M. Y., 2014. Development of a real-time PCR for detection of the oyster pathogen Nocardia crassostreae based on its homogeneous 16S-23S rRNA intergenic spacer region. Journal of Invertebrate Pathology. 114, 120-127.

Casadevall, A., Pirofski, L. A., 2009. Virulence factors and their mechanisms of action: the view from a damage-response framework. J Water Health. 7 Suppl 1, S2-S18.

Castro, D., Martinezmanzanares, E., Luque, A., Fouz, B., Morinigo, M. A., Borrego, J. J., et al., 1992. Characterization of Strains Related to Brown Ring Disease Outbreaks in Southwestern Spain. Diseases Of Aquatic Organisms. 14, 229-236.

Choquet, G., Soudant, P., Lambert, C., Nicolas, J. L., Paillard, C., 2003. Reduction of adhesion properties of Ruditapes philippinarum hemocytes exposed to Vibrio tapetis. Dis Aquat Organ. $57,109-16$.

Cooney, R. P., Pantos, O., Le Tissier, M. D. A., Barer, M. R., O’Donnell, A. G., Bythell, J. C., 2002. Characterization of the bacterial consortium associated with black band disease in coral using molecular microbiological techniques. Environ Microbiol. 4, 401-413.

Crosson, L. M., Wight, N., VanBlaricom, G. R., Kiryu, I., Moore, J. D., Friedman, C. S., 2014. Abalone withering syndrome: distribution, impacts, current diagnostic methods and new findings. Dis Aquat Organ. 108, 261-70.

Davis-Scibienski, C., Beaman, B. L., 1980. Interaction of Nocardia asteroides with rabbit alveolar macrophages: effect of growth phase and biability on phagosome-lysosome fusion. Infection and Immunity. 29, 24-29.

Davis, C. V., Barber, B. J., 1994. Size-dependent mortality in hatchery-reared populations of oysters, Crassostrea virginica, Gmelin 1791, affected by juvenile oyster disease. Journal of Shellfish Research. 13, 137-142.

Davis, C. V., Barber, B. J., 1999. Growth and survival of selected lines of eastern oysters, Crassostrea virginica (Gmelin 1791) affected by juvenile oyster disease. Aquaculture 178, 253-271.

De Decker, S., Reynaud, Y., Saulnier, D., 2013. First molecular evidence of cross-species induction of metalloprotease gene expression in Vibrio strains pathogenic for Pacific oyster Crassostrea gigas involving a quorum sensing system. Aquaculture. 392, 1-7. 
de O Santos, E., Alves, N., Jr., Dias, G. M., Mazotto, A. M., Vermelho, A., Vora, G. J., et al., 2011. Genomic and proteomic analyses of the coral pathogen Vibrio coralliilyticus reveal a diverse virulence repertoire. ISME J. 5, 1471-83.

De Schryver, P., Vadstein, O., 2014. Ecological theory as a foundation to control pathogenic invasion in aquaculture. ISME J. 8, 2360-2368.

Dégremont, L., Azéma, P., Travers, M. A., Spat and adult mortality related to Vibrio aestuarianus in Crassostrea gigas in France. National Shellfish Association Meeting, Jacksonville, Florida, USA, 2014.

Delgado, M., Carrasco, N., Elandaloussi, L., Furones, D., Roque, A., 2007. A mortality event of the venerid bivalve Callista chione (Linnaeus, 1758) in a hatchery system - A case study. Bull. Eur. Ass. Fish Pathol. 27, 214.

Delston, R. B., Kothary, M. H., Shangraw, K. A., Tall, B. D., 2003. Isolation and characterization of a zinc-containing metalloprotease expressed by Vibrio tubiashii. Canadian Journal of Microbiology. 49, 525-529.

Dieguez, A. L., Beaz-Hidalgo, R., Cleenwerck, I., Balboa, S., de Vos, P., Romalde, J. L., 2011. Vibrio atlanticus sp nov and Vibrio artabrorum sp nov., isolated from the clams Ruditapes philippinarum and Ruditapes decussatus. International Journal of Systematic and Evolutionary Microbiology. 61, 2406-2411.

Dorfmeier, E., 2012. Ocean acidification and disease: How will a changing climate impact Vibrio tubiashii growth and pathogenicity to Pacific oyster larvae? MS Thesis, University of Washington

Drummond, L. C., Balboa, S., Beaz, R., Mulcahy, M. F., Barja, J. L., Culloty, S. C., et al., 2007. The susceptibility of Irish-grown and Galician-grown Manila clams, Ruditapes philippinarum, to Vibrio tapetis and Brown Ring Disease. Journal of Invertebrate Pathology. 95, 1-8.

Drummond, L. C., O'Reilly, P., Mulcahy, M. F., Culloty, S. C., 2006. Comparison of techniques for diagnosis of Brown Ring Disease and detection of Vibrio tapetis in the Manila clam, Venerupis (Ruditapes) philippinarum. Journal of Shellfish Research 25, 1043-1049.

Duperthuy, M., Binesse, J., Le Roux, F., Romestand, B., Caro, A., Got, P., et al., 2010. The major outer membrane protein OmpU of Vibrio splendidus contributes to host antimicrobial peptide resistance and is required for virulence in the oyster Crassostrea gigas. Environmental Microbiology. 12, 951-963.

Duperthuy, M., Schmitt, P., Garzon, E., Caro, A., Rosa, R. D., Le Roux, F., et al., 2011. Use of OmpU porins for attachment and invasion of Crassostrea gigas immune cells by the oyster pathogen Vibrio splendidus. Proceedings of the National Academy of Sciences of the United States of America. 108, 2993-2998.

Elston, R., 1986. Occurrence of branchial rickettsiales-like infections in two bivalves molluscs, Tapes japonica and Patinopecten yessoensis, with comments on their significance. Journal of Fish Diseases. 9, 69-71.

Elston, R. A., Beattie, J. H., Friedman, C., Hedrick, R., Kent, M. L., 1987. Pathology and significance of fatal inflammatory bacteraemia in the Pacific oyster, Crassostrea gigas. Journal of Fish Diseases. 10, 121-132.

Elston, R. A., Hasegawa, H., Humphrey, K. L., Polyak, I. K., xe, se, C. C., 2008. Re-emergence of Vibrio tubiashii in bivalve shellfish aquaculture: severity, environmental drivers, geographic extent and management. Diseases of Aquatic Organisms. 82, 119-134.

Engelsma, M. Y., Roozenburg, I., Joly, J. P., 2008. Isolation of Nocarida crassostreae from Pacific oyster Crassostrea gigas in Europe. Diseases of Aquatic Organisms 80, 229-234.

Erauso, G., Lakhal, F., Bidault-Toffin, A., Le Chevalier, P., Bouloc, P., Paillard, C., et al., 2011. Evidence for the Role of Horizontal Transfer in Generating pVT1, a Large Mosaic Conjugative Plasmid from the Clam Pathogen, Vibrio tapetis. Plos One. 6.

Estes, R. M., Friedman, C. S., Elston, R. A., Herwig, R. P., 2004. Pathogenicity testing of shellfish hatchery bacterial isolates on Pacific oyster Crassostrea gigas larvae. Dis Aquat Organ. 58, 223-30.

Euzeby, J., List of prokaryotic names with standing in nomenclature. 2011, pp. http://www.bacterio.cict.fr/a/actinobacteria. 
Farley, C. A., Wolf, P. H., Elston, R. A., 1988. A long-term study of "microcell" disease in oysters with a description of a new genus, Mikrocytos (g. n.), and two new species, Mikrocytos mackini (sp. n.) and Mikrocytos roughleyi (sp. n.). Fishery Bulletin. 86, pp. 581-594.

Farto, R., Montes, M., Perez, M. J., Nieto, T. P., Larsen, J. L., Pedersen, K., 1999. Characterization by numerical taxonomy and ribotyping of Vibrio splendidus biovar I and Vibrio scophthalmi strains associated with turbot cultures. J Appl Microbiol. 86, 796-804.

Faury, N., Saulnier, D., Thompson, F. L., Gay, M., Swings, J., Roux, F. L., 2004. Vibrio crassostreae sp. nov., isolated from the haemolymph of oysters (Crassostrea gigas). Int J Syst Evol Microbiol. 54, 2137-40.

Felsheim, R. F., Kurtti, T. J., Munderloh, U. G., 2009. Genome Sequence of the Endosymbiont Rickettsia peacockii and Comparison with Virulent Rickettsia rickettsii: Identification of Virulence Factors. Plos One. 4, e8361.

Ferrantini, F., Fokin, S. I., Modeo, L., Andreoli, I., Dini, F., Gortz, H.-D., et al., 2009. "Candidatus Cryptoprodotis polytropus," A novel Rickettsia-like organism in the ciliated protist Pseudomicrothorax dubius (Ciliophora, Nassophorea). . Journal of Eukaryotic Microbiology. 56, 119-129.

Flassch, J. P., Barret, J., Mazurié, J., Maes, P., Nicolas, J. L., Noel, T., et al., 1992. L'élevage de la palourde, programme national de recherche sur la maladie de l'anneau brun. Les mollusques marins. Biologie et Aquaculture.

Flye-Sainte-Marie, J., Jean, F., Paillard, C., Kooijman, S. A. L. M., 2009a. A quantitative estimation of the energetic cost of brown ring disease in the Manila clam using Dynamic Energy Budget theory. Journal of Sea Research. 62, 114-123.

Flye-Sainte-Marie, J., Soudant, P., Lambert, C., Le Goïc, N., Goncalvez, M., Travers, M.-A., et al., 2009b. Variability of the hemocyte parameters of Ruditapes philippinarum in the field during an annual cycle. Journal of Experimental Marine Biology and Ecology. 377, 1-11.

Ford, S. E., Borrero, F. J., 2001. Epizootiology and pathology of Juvenile Oyster Disease in the eastern oyster, Crassostrea virginica. . Journal of Invertabrate Pathology. 78, 141-154.

Ford, S. E., Tripp, M. R., Diseases and defense mechanisms. The American Oyster, Crassotrea virginica, 1996, pp. 581-600.

Fournier, P. E., El Karkouri, K., Leroy, Q., Robert, C., Giumelli, B., Renesto, P., et al., 2009. Analysis of the Rickettsia africae genome reveals that virulence acquisition in Rickettsia species may be explained by genome reduction. Bmc Genomics. 10, 166.

Fournier, P. E., Raoult, D., 2009. Current knowledge on phylogeny and taxonomy of Rickettsia spp. Ann N Y Acad Sci. 1166, 1-11.

Friedman, C. S., Andree, K. B., Beauchamp, K. A., Moore, J. D., Robbins, T. T., Shields, J. D., et al., 2000. 'Candidatus Xenohaliotis californiensis', a newly described pathogen of abalone, Haliotis spp., along the west coast of North America. Int J Syst Evol Microbiol. 50 Pt 2, 84755 .

Friedman, C. S., Beaman, B. L., Chun, J., Goodfellow, M., Gee, A., Hedrick, R. P., 1998. Nocardia crassostreae sp. nov., the causal agent of nocardiosis in Pacific oysters. International Journal of Systematic Bacteriology. 48 Pt 1, 237-46.

Friedman, C. S., Beattie, J. H., Elston, R. A., Hedrick, R. P., 1991. Investigation of the relationship between the presence of a Gram-positive bacterial infection and summer mortality of the Pacific oyster, Crassostrea gigas Thunberg. Aquaculture. 94, 1-15.

Friedman, C. S., Biggs, W., Shields, J. D., Hedrick, R. P., 2002a. Transmission of Withering Syndrome in black abalone, Haliotis cracherodii Leach. . Journal of Shellfish Research. 21, 817-824.

Friedman, C. S., Biggs, W., Shields, J. D., Hedrick, R. P., 2002b. Transmission of Withering Syndrome in black abalone, Haliotis cracherodii Leach. journal of shellfish Research. 21, 817-824.

Friedman, C. S., Crosson, L. M., 2012. Putative phage hyperparasite in the rickettsial pathogen of abalone, "Candidatus Xenohaliotis californiensis". Microb Ecol. 64, 1064-72.

Friedman, C. S., Hedrick, R. P., 1991. Pacific oyster nocardiosis: Isolation of the bacterium and induction of laboratory infections. Journal of Invertebrate Pathology. 57, 109. 
Fujita, T., Matsubara, T., Hirokawa, H., Araki, F., 1953. On the inflammatorious changes of the Ostrea gigas in Hiroshima Bay. . Bulletin of the Japanese Society of Fisheries Science 19, 766-770.

Fujita, T., Matsubara, T., Hirokawa, H., Araki, F., 1955. On the inflammatorious changes of the Ostrea gigas in Hiroshima Bay-II. Bulletin of the Japanese Society of Fisheries Science. 20, 1063-1065.

Garnier, M., Labreuche, Y., Garcia, C., Robert, A., Nicolas, J. L., 2007. Evidence for the involvement of pathogenic bacteria in summer mortalities of the Pacific oyster Crassostrea gigas. Microbial Ecology. 53, 187-196.

Garnier, M., Labreuche, Y., Nicolas, J.-L., 2008. Molecular and phenotypic characterization of Vibrio aestuarianus subsp francensis subsp nov., a pathogen of the oyster Crassostrea gigas. Systematic and Applied Microbiology. 31, 358-365.

Gauger, E. J., Gomez-Chiarri, M., 2002. 16S ribosomal DNA sequencing confirms the synonymy of Vibrio harveyi and $V$. carchariae. Dis Aquat Organ. 52, 39-46.

Gay, M., Berthe, F. C., Le Roux, F., 2004a. Screening of Vibrio isolates to develop an experimental infection model in the Pacific oyster Crassostrea gigas. Dis Aquat Organ. 59, 49-56.

Gay, M., Lancelot, G., Chollet, B., Renault, T., Cochennec, N., Berthe, F., et al., 2003. Characterization of Vibrio isolated from Pacific oysters' spat suffering from summer mortality outbreaks. Journal of Shellfish Research [J. Shellfish Res.]. Vol. 22. no. 1.

Gay, M., Renault, T., Pons, A. M., Le Roux, F., 2004b. Two vibrio splendidus related strains collaborate to kill Crassostrea gigas: taxonomy and host alterations. Dis Aquat Organ. 62, 6574.

Genard, B., Miner, P., Nicolas, J. L., Moraga, D., Boudry, P., Pernet, F., et al., 2013. Integrative study of physiological changes associated with bacterial infection in Pacific oyster larvae. PLoS ONE. 8, e64534.

Gevers, D., Cohan, F. M., Lawrence, J. G., Spratt, B. G., Coenye, T., Feil, E. J., et al., 2005. Reevaluating Prokaryotic species. Nature Reviews Microbiology. 3, 733-739.

Gharaibeh, D. N., Biel, F. M., Hase, C. C., 2013. Development of monoclonal antibody-based assays for the detection of Vibrio tubiashii zinc-metalloprotease (VtpA). J Microbiol Methods. 94, $125-32$.

Gharaibeh, D. N., Hasegawa, H., Hase, C. C., 2009. Development of a quantitative real-time PCR assay for detection of Vibrio tubiashii targeting the metalloprotease gene. J Microbiol Methods. 76, 262-8.

Glude, J. B., A summary report of Pacific coast oyster mortality investigations., Proceedings of the Third US.- Japan Meeting on Aquaculture. Special Publication of Fishery Agency, Japanese Government and Japan Sea Regional Fisheries Research Laboratory, Tokyo, Japan, 1975.

Godwin, S., Bent, E., Borneman, J., Pereg, L., 2012. The Role of Coral-Associated Bacterial Communities in Australian Subtropical White Syndrome of Turbinaria mesenterina. Plos One. 7, e44243.

Gollas-Galvan, T., Avila-Villa, L. A., Martınez-Porchas, M., Hernandez-Lopez, J., 2013. Rickettsialike organisms fromcultured aquatic organisms, with emphasis on necrotizing hepatopancreatitis bacterium affecting penaeid shrimp: an overview on an emergent concern. Reviews in Aquaculture. 5, 1-14.

Gomez-Gil, B., Soto-Rodriguez, S., Garcia-Gasca, A., Roque, A., Vazquez-Juarez, R., Thompson, F. L., et al., 2004. Molecular identification of Vibrio harveyi-related isolates associated with diseased aquatic organisms. Microbiology. 150, 1769-77.

Gomez-Leon, J., Aranguren, R., Gestal, C., Novoa, B., A., F., 2007. Temporal distribution of potentially pathogenic agents detected on carpet-shell clam, Ruditapes decussatus cultured in Galicia (NW Spain). Aquat Living Resour. 20, 185-189.

Gomez-Leon, J., Villamil, L., Lemos, M. L., Novoa, B., Figueras, A., 2005. Isolation of Vibrio alginolyticus and Vibrio splendidus from aquacultured carpet shell clam (Ruditapes decussatus) larvae associated with mass mortalities. Appl Environ Microbiol. 71, 98-104.

Gomez-Leon, J., Villamil, L., Salger, S. A., Sallum, R. H., Remacha-Trivino, A., Leavitt, D. F., et al., 2008. Survival of eastern oysters Crassostrea virginica from three lines following experimental challenge with bacterial pathogens. Dis Aquat Organ. 79, 95-105. 
Goudenege, D., Travers, M. A., Lemire, A., Petton, B., Haffner, P., Labreuche, Y., et al., 2015. A single regulatory gene is sufficient to alter Vibrio aestuarianus pathogenicity in oysters. Environ Microbiol. http://dx.doi.org/10.1111/1462-2920.12699

Guillard, R. R. L., 1959. Further evidence of the destruction of bivalve larvae by bacteria. Biol Bull. $117,258-266$.

Guisande, J. A., Montes, M., Farto, R., Armada, S. P., Perez, M. J., Nieto, T. P., 2004. A set of tests for the phenotypic identification of culturable bacteria associated with Galician bivalve mollusc production. Journal of Shellfish Research. 23, 599-609.

Guo, X., Ford, S. E., DeBrosse, G., Smolowitz, R., Sunila, I., 2003. Breeding and evaluation of eastern oyster strains selected for MSX, Dermo and JOD resistance. Journal of Shellfish Research. 22, 353-354 (abstract).

Hada, H. S., West, P. A., Lee, J. V., Stemmler, J., Coldwell, R. R., 1984. Vibrio tubiashii sp. nov., a pathogen of bivalve mollusks. Int J Syst Bacteriol. 34, 1-4.

Harshbarger, J. C., Chang, S. C., Otto, S. V., 1977. Chlamydiae (with phages), Mycoplamas, and Rickettsiae in Chesapeake Bay Bivalves. Science. 196, 666-668.

Harvell, C. D., Mitchell, C. E., Ward, J. R., Altizer, S., Dobson, A. P., Ostfeld, R. S., et al., 2002. Climate warming and disease risks for terrestrial and marine biota. Science. 296, 2158-62.

Hasegawa, H., Gharaibeh, D. N., Lind, E. J., Hase, C. C., 2009. Virulence of metalloproteases produced by Vibrio species on Pacific oyster Crassostrea gigas larvae. Diseases of Aquatic Organisms. 85, 123-131.

Hasegawa, H., Hase, C. C., 2009. The extracellular metalloprotease of Vibrio tubiashii directly inhibits its extracellular haemolysin. Microbiology-Sgm. 155, 2296-2305.

Hasegawa, H., Lind, E. J., Boin, M. A., Hase, C. C., 2008. The extracellular metalloprotease of Vibrio tubiashii is a major virulence factor for Pacific oyster (Crassostrea gigas) larvae. Applied and Environmental Microbiology. 74, 4101-4110.

Hernandez, G., Olmos, J., 2004. Molecular identification of pathogenic and nonpathogenic strains of Vibrio harveyi using PCR and RAPD. Appl Microbiol Biotechnol. 63, 722-7.

Hoffmann, M., Monday, S. R., Fischer, M., Brown, E. W., 2012. Genetic and phylogenetic evidence for misidentification of Vibrio species within the Harveyi clade. Lett Appl Microbiol. 54, 1605.

Hunt, D. E., David, L. A., Gevers, D., Preheim, S. P., Alm, E. J., Polz, M. F., 2008. Resource partitioning and sympatric differentiation among closely related bacterioplankton. Science. 320, 1081-5.

Ifremer, Vibrio splendidus and $V$. aestuarianus detection by Real Time Polymerase Chain Reaction. European Union Reference Laboratory for Molluscs Diseases. In: L. d. G. e. P. d. M. Marins, (Ed.), 2013.

Imai, T., Mori, K., Sugawara, Y., Tamate, H., Oizumi, J., Itikawa, O., 1968. Studies on the mass mortalitiy of oysters in Matsushima bay VII. Pathogenic investigation. Tohoku Journal of Agricultural Research. 19, 250-265.

Imai, T., Numachi, K., Oizumi, J., Sato, S., 1965. Studies on the mass mortality of the oyster in Matsushima Bay. II. Search for the cause of mass mortality and the possibility to prevent it by transplantation experiment. Bull. Tohoku Reg. Fish. Res. Lab. 25, 27-38.

Jang, J., Jung, K.-T., Park, J., Yoo, C.-K., Rhie, G.-E., 2011. The Vibrio cholerae VarS/VarA twocomponent system controls the expression of virulence proteins through ToxT regulation. Microbiology-Sgm. 157, 1466-1473.

Jeffries, V. E., 1982. Three Vibrio strains pathogenic to larvae of Crassostrea gigas and Ostrea edulis. Aquaculture. 29, 201-226.

Jeffroy, F., Paillard, C., 2011. Involvement of nitric oxide in the in vitro interaction between Manila clam, Ruditapes philippinarum, hemocytes and the bacterium Vibrio tapetis. Fish Shellfish Immunol. 31, 1137-41.

Jensen, S., Samuelsen, O. B., Andersen, K., Torkildsen, L., Lambert, C., Choquet, G., et al., 2003. Characterization of strains of Vibrio splendidus and $V$. tapetis isolated from corkwing wrasse Symphodus melops suffering vibriosis. Dis Aquat Organ. 53, 25-31.

Jones, J. B., Review of pearl oyster mortalities and disease problems. In: M. G. Bondad-Reantaso, et al., Eds.), Pearl Oyster Health Management: A Manual, FAO, Rome., 2007, pp. 61-70. 
Katkansky, S. C., Warner, R. W., Pacific oyster disease and mortality studies in California., Marine Resources Technical Report, Vol. 25. California Dept. of Fish and Game, Long Beach, 1974.

Kesarcodi-Watson, A., Kaspar, H., Lategan, M. J., Gibson, L., 2008. Probiotics in aquaculture: The need, principles and mechanisms of action and screening processes. Aquaculture. 274, 1-14.

Kesarcodi-Watson, A., Kaspar, H., Lategan, M. J., Gibson, L., 2009a. Two pathogens of Greenshell (TM) mussel larvae, Perna canaliculus: Vibrio splendidus and a V-coralliilyticus/neptuniuslike isolate. Journal of Fish Diseases. 32, 499-507.

Kesarcodi-Watson, A., Kaspar, H., Lategan, M. J., Gibson, L. F., 2009b. Challenge of New Zealand Greenshell (TM) mussel Perna canaliculus larvae using two Vibrio pathogens: a hatchery study. Diseases of Aquatic Organisms. 86, 15-20.

Kim, D., Baik, K. S., Hwang, Y. S., Choi, J. S., Kwon, J., Seong, C. N., 2013. Vibrio hemicentroti sp. nov., an alginate lyase-producing bacterium, isolated from the gut microflora of sea urchin (Hemicentrotus pulcherrimus). Int J Syst Evol Microbiol. 63, 3697-703.

Kimes, N. E., Grim, C. J., Johnson, W. R., Hasan, N. A., Tall, B. D., Kothary, M. H., et al., 2012. Temperature regulation of virulence factors in the pathogen Vibrio coralliilyticus. ISME J. 6, 835-46.

Kita-Tsukamoto, K., Wada, M., Yao, K., Kamiya, A., Yoshizawa, S., Uchiyama, N., et al., 2006. Rapid identification of marine bioluminescent bacteria by amplified 16S ribosomal RNA gene restriction analysis. FEMS Microbiol Lett. 256, 298-303.

Koganezawa, A., Present status of studies on the mass mortality of cultured oysters in Japan and its prevention., Proceedings of the Third U.S.-Japan Meeting on Aquaculture, Tokyo. Japan. , 1974, pp. 29-34. .

Kothary, M. H., Delston, R. B., Curtis, S. K., McCardell, B. A., Tall, B. D., 2001. Purification and characterization of a vulnificolysin-like cytolysin produced by Vibrio tubiashii. Appl Environ Microbiol. 67, 3707-11.

Labreuche, Y., Lambert, C., Soudant, P., Boulo, V., Huvet, A., Nicolas, J.-L., 2006a. Cellular and molecular hemocyte responses of the Pacific oyster, Crassostrea gigas, following bacterial infection with Vibrio aestuarianus strain 01/32. Microbes and Infection. 8, 2715-2724.

Labreuche, Y., Le Roux, F., Henry, J., Zatylny, C., Huvet, A., Lambert, C., et a1., 2010. Vibrio aestuarianus zinc metalloprotease causes lethality in the Pacific oyster Crassostrea gigas and impairs the host cellular immune defenses. Fish \& Shellfish Immunology. 29, 753-758.

Labreuche, Y., Soudant, P., Goncalves, M., Lambert, C., Nicolas, J. L., 2006b. Effects of extracellular products from the pathogenic Vibrio aestuarianus strain 01/32 on lethality and cellular immune responses of the oyster Crassostrea gigas. Developmental and Comparative Immunology, 30, 367-379.

Lacoste, A., Jalabert, F., Malham, S., Cueff, A., Gelebart, F., Cordevant, C., et al., 2001. A Vibrio splendidus strain is associated with summer mortality of juvenile oysters Crassostrea gigas in the Bay of Morlaix (North Brittany, France). Diseases of Aquatic Organisms. 46, 139-145.

Lago, E. P., Nieto, T. P., Seguin, R. F., 2009. Fast detection of Vibrio species potentially pathogenic for mollusc. Veterinary Microbiology. 139, 339-346.

Lakhal, F., Bury-Mone, S., Nomane, Y., Le Goic, N., Paillard, C., Jacq, A., 2008. Dj1A, a membraneanchored DnaJ-like protein, is required for cytotoxicity of clam pathogen Vibrio tapetis to hemocytes. Appl Environ Microbiol. 74, 5750-8.

Lambert, C., Nicolas, J., Cilia, V., 1999. Vibrio splendidus-related strain isolated from brown deposit in scallop (Pecten maximus) cultured in Brittany (France). Bull. Eur. Ass. Fish Pathol. 19, 102.

Lasa, A., Diéguez, A. L., Romalde, J. L., 2013. Vibrio toranzoniae sp. nov., a new member of the Splendidus clade in the genus Vibrio. Systematic and Applied Microbiology. 36, 96-100.

Le Roux, F., Binesse, J., Saulnier, D., Mazel, D., 2007. Construction of a Vibrio splendidus mutant lacking the metalloprotease gene vsm by use of a novel counterselectable suicide vector. Appl Environ Microbiol. 73, 777-784.

Le Roux, F., Gay, M., Lambert, C., Nicolas, J. L., Gouy, M., Berthe, F., 2004. Phylogenetic study and identification of Vibrio splendidus-related strains based on gyrB gene sequences. Dis Aquat Organ. 58, 143-50. 
Le Roux, F., Gay, M., Lambert, C., Waechter, M., Poubalanne, S., Chollet, B., et al., 2002. Comparative analysis of Vibrio splendidus-related strains isolated during Crassostrea gigas mortality events. Aquatic Living Resources. 15, 251-258.

Le Roux, F., Goubet, A., Thompson, F. L., Faury, N., Gay, M., Swings, J., et al., 2005. Vibrio gigantis sp. nov., isolated from the haemolymph of cultured oysters (Crassostrea gigas). Int J Syst Evol Microbiol. 55, 2251-2255.

Le Roux, F., Zouine, M., Chakroun, N., Binesse, J., Saulnier, D., Bouchier, C., et al., 2009. Genome sequence of Vibrio splendidus: an abundant planctonic marine species with a large genotypic diversity. Environmental Microbiology. 11, 1959-1970.

Lee, K. K., Chen, Y. L., Liu, P. C., 1999. Hemostasis of tiger prawn Penaeus monodon affected by Vibrio harveyi, extracellular products and a toxic cysteine protease. Blood Cells Molecules and Diseases. 25, 181-193.

Lee, K. K., Liu, P. C., Chuang, W. H., 2002. Pathogenesis of gastroenteritis caused by Vibrio carchariae in cultured marine fish. Mar Biotechnol (NY). 4, $267-77$.

Lee, L. H., Azman, A. S., Zainal, N., Eng, S. K., Fang, C. M., Hong, K., et al., 2014. Novosphingobium malaysiense sp. nov. isolated from mangrove sediment. Int J Syst Evol Microbiol. 64, 1194-201.

Lemire, A., Goudenege, D., Versigny, T., Petton, B., Calteau, A., Labreuche, Y., et al., 2014. Populations, not clones, are the unit of vibrio pathogenesis in naturally infected oysters. ISME J. $1-9$

Li, D., Wu, X., 2004. Purification and biological features of a rickettsia-like prokaryote from the scallop Argopecten irradians in China Aquaculture. 234, 29-40.

Lindsay, C. E., Summary of progress of Pacific oyster mass mortality investigations. 21st Annual Report of the Pacific Marine Fisheries Commission for the Year 1968. , Vol. 1967-68, 1969, pp. 36-38.

Liu, P. C., Chen, Y. C., Huang, C. Y., Lee, K. K., 2000. Virulence of Vibrio parahaemolyticus isolated from cultured small abalone Haliotis diversicolor supertexta with withering syndrome. . Letters in applied Microbiology. 31, 433-437.

Lodeiros, C., Bolinches, J., Dopazo, C. P., Torenzo, A. A., 1987. Bacillary necrosis in hatcheries of Ostrea edulis in Spain. Aquaculture. 65, 15-29.

Lopez, J. R., Balboa, S., Nunez, S., de la Roca, E., de la Herran, R., Navas, J. I., et al., 2011. Characterization of Vibrio tapetis strains isolated from diseased cultured Wedge sole (Dicologoglossa cuneata Moreau). Research in Veterinary Science. 90, 189-195.

Macian, M. C., Ludwig, W., Aznar, R., Grimont, P. A., Schleifer, K. H., Garay, E., et al., 2001. Vibrio lentus sp. nov., isolated from Mediterranean oysters. Int J Syst Evol Microbiol. 51, 1449-56.

Macián, M. C., Ludwig, W., Schleifer, K.-H., Garay, E., Pujalte, M. J., 2000. Vibrio pelagius: differences of the type strain deposited at various culture collections. Syst Appl Microbiol. 23, 373-375.

Madec, S., Pichereau, V., Jacq, A., Paillard, M., Boisset, C., Guérard, F., et al., 2014. Characterization of the secretomes of two Vibrios pathogenic to mollusks. PLoS ONE. 9, pp.0113097.

Maes, P., Paillard, C., 1992 Effet du Vibrio P1, pathogène de Ruditapes philippinarum, sur d'autres espèces de bivalves. LES MOLLUSQUES MARINS. BIOLOGIE ET AQUACULTURE. Ifremer, Actes de Colloques. 14, 141-148.

Maloy, A. P., Barber, B. J., Boettcher, K. J., 2005. A PCR-based diagnostic assay for the detection of Roseovarius crassostreae in Crassostrea virginica affected by juvenile oyster disease (JOD) Dis Aquat Org. 67, 155-162.

Maloy, A. P., Barber, B. J., Boettcher, K. J., 2007a. Use of the 16S-23S rDNA internal transcribed spacer of Roseovarius crassostreae for epizootiological studies of juvenile oyster disease (JOD). Dis Aquat Organ. 76, 151-61.

Maloy, A. P., Ford, S. E., Karney, R. C., Boettcher, K. J., 2007b. Roseovarius crassostreae, the etiological agent of Juvenile Oyster Disease (now to be known as Roseovarius Oyster Disease) in Crassostrea virginica. . Aquaculture. 269, 71-83.

Matsuyama, T., Sakai, T., Kiryu, I., Yuasa, K., Yasunobu, H., Kawamura, Y., et al., 2010. First Isolation of Vibrio tapetis, the Etiological Agent of Brown Ring Disease (BRD), in Manila Clam Ruditapes philippinarum in Japan. Fish Pathology. 45, 77-79. 
McDowell, I. C., Nikapitiya, C., Aguiar, D., Lane, C. E., Istrail, S., Gomez-Chiarri, M., 2014. Transcriptome of American Oysters, Crassostrea virginica, in Response to Bacterial Challenge: Insights into Potential Mechanisms of Disease Resistance. PLoS ONE. 9, e105097.

Mersni Achour, R., Ben Cheick, Y., Pichereau, V., Doghri, I., Etien, C., Dégremont, L., et al., 2015. Factors other than metalloprotease are required for full virulence of French Vibrio tubiashii isolates in oyster larvae. Microbiology. 161, 997-1007.

Mersni Achour, R., Imbert, N., Huet, V., Ben Cheick, Y., Faury, N., Doghri, I., et al., 2014. First description of French $V$. tubiashii strains pathogenic to mollusk: II. Charasterization of the proteolytic fraction of extracellular products. J Invertebr Pathol. 123, 49-59.

Murray, A. G., Marcos-Lopez, M., Collet, B., Munro, L. A., 2012. A review of the risk posed to Scottish mollusc aquaculture from Bonamia, Marteilia and oyster herpesvirus. Aquaculture. 370-371, 7-13.

Nicolas, J., Corre, S., Gauthier, G., Robert, R., Ansquer, D., 1996. Bacterial problems associated with scallop Pecten maximus larval culture Diseases of Aquatic Organisms. 27, 67-76.

Nicolas, J. L., Basuyaux, O., Mazurie, J., Thebault, A., 2002. Vibrio carchariae, a pathogen of the abalone Haliotis tuberculata. Dis Aquat Organ. 50, 35-43.

Nottage, A. S., Birkbeck, T. H., 1987. Production of Proteinase During Experimental-Infection of Ostrea-Edulis L Larvae with Vibrio-Alginolyticus Ncmb-1339 and the Antigenic Relationship between Proteinases Produced by Marine Vibrios Pathogenic for Fish and Shellfish. Journal of Fish Diseases. 10, 265-273.

Numachi, K., Oizumi, J., 1965. The pathological changes of the oyster caused by Gram-positive bacteria and the frequency of their infection. . Bull. Tohoku Reg. Fish. Res. Lab. 25, 39-47.

Olafsen, J. A., Mikkelsen, H. V., Giaever, H. M., Hovik Hansen, G., 1993. Indigenous bacteria in hemolymph and tissues of marine bivalves at low temperatures. Appl Environ Microbiol. 59, 1848-54.

Oliveira, J., Castilho, F., Cunha, A., Pereira, M. J., 2012. Bacteriophage therapy as a bacterial control strategy in aquaculture. Aquacult Int. 20, 879-910.

Oubella, R., Maes, P., Allam, B., Paillard, C., Auffret, M., 1996. Selective induction of hemocytic response in Ruditapes philippinarum (Bivalvia) by different species of Vibrio (Bacteria). Aquatic Living Resources. 9, 137-143.

Oubella, R., Paillard, C., Maes, P., Auffret, M., 1994. Changes in Hemolymph Parameters in the Manila Clam Ruditapes-Philippinarum (Mollusca, Bivalvia) Following Bacterial Challenge. Journal of Invertebrate Pathology. 64, 33-38.

Paillard, C., Gausson, S., Nicolas, J. L., le Pennec, J. P., Haras, D., 2006. Molecular identification of Vibrio tapetis, the causative agent of the brown ring disease of Ruditapes philippinarum. Aquaculture. 253, 25-38.

Paillard, C., Korsnes, K., Le Chevalier, P., Le Boulay, C., Harkestad, L., Eriksen, A. G., et al., 2008. Vibrio tapetis-like strain isolated from introduced Manila clams Ruditapes philippinarum showing symptoms of brown ring disease in Norway. Diseases Of Aquatic Organisms. 81, 153-161.

Paillard, C., Le Roux, F., Borrego, J. J., 2004. Bacterial disease in marine bivalves, a review of recent studies: Trends and evolution Aquatic Living Resources. 17, 477-498

Paillard, C., Maes, P., 1990. Etiologie de la maladie de l'anneau brun chez Tapes philippinarum : pathogénicité d'un Vibrio sp. Comptes Rendus de l'Academie des Sciences - Series III Sciences de la Vie. 310, 15-20.

Paillard, C., Maes, P., Oubella, R., 1994. Brown ring disease in clams. Annual Review of Fish Diseases. 4, 219-240.

Pantos, O., Bythell, J. C., 2006. Bacterial community structure associated with white band disease in the elkhorn coral Acropora palmata determined using culture-independent 16S rRNA techniques. Diseases of Aquatic Organisms. 69, 79-88.

Park, K. I., Tsutsumi, H., Hong, J. S., Choi, K. S., 2008. Pathology survey of the short-neck clam Ruditapes philippinarum occurring on sandy tidal flats along the coast of Ariake Bay, Kyushu, Japan. J Invertebr Pathol. 99, 212-219.

Parsek, M. R., Greenberg, E. P., 2005. Sociomicrobiology: the connections between quorum sensing and biofilms. Trends Microbiol 13, 27-33. 
Pass, D. A., Dybadahl, R., Manion, M. M., 1987 Investigations into the causes of mortality in the peral oyster Pinctata maxima (Jamson) in western Australia. . Aquaculture. 65, 149-169.

Paul-Pont, I., de Montaudouin, X., Gonzalez, P., Jude, F., Raymond, N., Paillard, C., et al., 2010. Interactive effects of metal contamination and pathogenic organisms on the introduced marine bivalve Ruditapes philippinarum in European populations. Environmental Pollution. 158, 3401-3410.

Perdue, J. A., Beattie, J. H., Chew, K. K., 1981. Some relationships between gametogenic cycle and summer mortality phenomenon in the Pacific oyster (C. gigas) in Washington state. J. Shell. Research. 1, 9-16.

Plana, S., Sinquin, G., Maes, P., Paillard, C., Le Pennec, M., 1996. Variations in biochemical composition of juvenile Ruditapes philippinarum infected by a Vibrio sp. Dis Aquat Org. 24, 205-213.

Pollock, F. J., Morris, P. J., Willis, B. L., Bourne, D. G., 2010a. Detection and quantification of the coral pathogen Vibrio coralliilyticus by real-time PCR with TaqMan fluorescent probes. Appl Environ Microbiol. 76, 5282-6.

Pollock, F. J., Wilson, B., Johnson, W. R., Morris, P. J., Willis, B. L., Bourne, D. G., 2010 b. Phylogeny of the coral pathogen Vibrio coralliilyticus. Environ Microbiol Rep. 2, 172-8.

Prado, S., Romalde, J., Montes, J., Barja, J. L., 2005. Pathogenic bacteria isolated from disease outbreaks in shellfish hatcheries. First description of Vibrio neptunius as an oyster pathogen Dis Aquat Org. 67, 209-215.

Pujalte, M. J., Sitja-Bobadilla, A., Macian, M. C., Belloch, C., Alvarez-Pellitero, P., Perez-Sanchez, J., et al., 2003. Virulence and molecular typing of Vibrio harveyi strains isolated from cultured dentex, gilthead sea bream and European sea bass. Syst Appl Microbiol. 26, 284-92.

Quayle, D. B., 1961. Denman Island disease and mortalities, 1960. Fisheries Research Board of Canada. 713, 1-9.

Rawson, P., Feindel, S., 2012. Growth and survival for genetically improved lines of Eastern oysters (Crassostrea virginica) and interline hybrids in Maine, USA. Aquaculture. 326-329, 61-67.

Reichalt, J. L., Baumann, P., Baumann, L., 1976. Study of genetic relationships among marine species of the genera Beneckea and Photobacterium by means of in vitro DNA/DNA hybridization. Arch Microbiol. 110, 101-120.

Reid, H. I., Duncan, H. L., Laidler, L. A., Hunter, D., Birkbeck, T. H., 2003. Isolation of Vibrio tapetis from cultivated Atlantic halibut (Hippoglossus hippoglossus L.). Aquaculture. 221, 65.

Renault, T., Cochennec, N., 1994. Rickettsia-like organisms in the cytoplasm of gill epithelial cells of the Pacific oyster Crassostrea gigas. Journal of Invertebrate Pathology. 64, 160-162.

Revol, A., Espinoza-Ruiz, M., Medina-Villanueva, I., Salinas-Carmona, M. C., 2006. Expression of Nocardia brasiliensis superoxide dismutase during the early infection of murine peritoneal macrophages. . Canadial Journal of Microbiology 52, 1255-1260.

Richards, G. P., Bono, J. L., Watson, M. A., Needleman, D. S., 2014a. Complete Genome Sequence for the Shellfish Pathogen Vibrio coralliilyticus RE98 Isolated from a Shellfish Hatchery. Genome Announc. 2.

Richards, G. P., Needleman, D. S., Watson, M. A., Bono, J. L., 2014b. Complete Genome Sequence of the Larval Shellfish Pathogen Vibrio tubiashii Type Strain ATCC 19109. Genome Announc. 2.

Rodriguez, J. M., Lopez-Romalde, S., Beaz, R., Alonso, M., Castro, D., Romalde, J. L., 2006. Molecular fingerprinting of Vibrio tapetis strains using three PCR-based methods: ERIC-PCR, REP-PCR and RAPD. Diseases of Aquatic Organisms 69, 175-183.

Romero, A., Costa, M. D., Forn-Cuni, G., Balseiro, P., Chamorro, R., Dios, S., et al., 2014. Occurrence, seasonality and infectivity of Vibrio strains in natural populations of mussels Mytilus galloprovincialis. Diseases Of Aquatic Organisms. 108, 149-163.

Roux, V., Raoult, D., 1995. Phylogenetic analysis of the genus Rickettsia by 16S rDNA sequencing. Research in Microbiology. 146, 385-396.

Ruwandeepika, H. A. D., Jayaweera, P. S., Bhowmick, P. P., Kuranagasar, I., Bossier, P., Defroidt, T., 2012. Pathogensesis, virulence factors and virulence regulation of vibrios belonging to the Harveyi clade. Rev in aquaculture. 4, 59-74. 
Sabry, R. C., da Silva, P. M., Gesteira, T. C. V., de Almeida Pontinha, V., Magalhães, A. R. M., 2011. Pathological study of oysters Crassostrea gigas from culture and C. rhizophorae from natural stock of Santa Catarina Island, SC, Brazil. Aquaculture. 60, 43-50.

Samain, J.-F., McCombie, H., 2008. Summer mortality of Pacific oyster Crassostrea gigas : the Morest project. Éd. Quae, Versailles.

Sathyamoorthy, V., Datta, A. R., Lee, C. J., Kothary, M. H., McCardell, B. A., Tall, B. D., 2011. Cloning and partial characterization of a novel hemolysin gene of Vibrio tubiashii and the development of a PCR-based detection assay. Can J Microbiol. 57, 714-21.

Saulnier, D., De Decker, S., Haffner, P., 2009. Real-time PCR assay for rapid detection and quantification of Vibrio aestuarianus in oyster and seawater: A useful tool for epidemiologic studies. Journal of Microbiological Methods. 77, 191-197.

Saulnier, D., De Decker, S., Haffner, P., Cobret, L., Robert, M., Garcia, C., 2010. A Lárge-Scale Epidemiological Study to Identify Bacteria Pathogenic to Pacific Oyster Crassostrea gigas and Correlation Between Virulence and Metalloprotease-like Activity. Microbial Ecology. 59, 787-798.

Sawabe, T., Kita-Tsukamoto, K., Thompson, F. L., 2007. Inferring the evolutionary history of vibrios by means of multilocus sequence analysis. Journal of Bacteriology. 189, 7932-7936.

Schikorski, D., Renault, T. P., C., Bidault-Toffin, A., Saulnier, D., 2014. Development of TaqMan real-time PCR assays for monitoring Vibrio harveyi infection and a plasmid harbored by virulent strains in European abalone Haliotis tuberculata aquaculture. 392, 106-112.

Schirrmeister, J., Zocher, S., Flor, L., Gottfert, M., Zehner, S., 2013. The domain of unknown function DUF1521 exhibits metal ion-inducible autocleavage activity - a novel example from a putative effector protein of Vibrio coralliilyticus ATCC BAA-450. FEMS Microbiol Lett. 343, 177-82.

Sinderman, C. J., Rosenfield, A., 1967. Principal diseases of commercially important marine bivalve Mollusca and Crustacea. Fish. Bull. U.S. Fish Wildlife Serv. 66, 335-385.

Stackebrandt, E., Rainey, F. A., Ward-Rainey, N. L., 1997. Proposal for a new hierarchic classification system, Actinobacteria classis nov. Int J Syst Bacteriol. 47, 479-491.

Sugumar, G., Nakai, T., Hirata, Y., Matsubara, D., Muroga, K., 1998. Vibrio splendidus biovar II as the causative agent of bacillary necrosis of Japanese oyster Crassostrea gigas larvae Diseases of Aquatic Organisms. 33, 111-118.

Suna, G. J., Wu, X., 2004. Histology, ultrastructure, and morphogenesis of a rickettsia-like organism causing disease in the oyster, Crassostrea ariakensis. . Journal of Invertabrate Pathology. 86, 77-86.

Sussman, M., Willis, B. L., Victor, S., Bourne, D. G., 2008. Coral pathogens identified for White Syndrome (WS) epizootics in the Indo-Pacific. Plos One. 3, e2393.

Tall, A., Hervio-Heath, D., Teillon, A., Boisset-Helbert, C., Delesmont, R., Bodilis, J., et al., 2013. Diversity of Vibrio spp. isolated at ambient environmental temperature in the Eastern English Channel as determined by pyrH sequencing. Journal of Applied Microbiology. 114, 17131724.

Tamate, H., Numachi, K., Mon, K., Liikawa, O., Imai, T., 1965. Studies on the mass mortality of the oyster in Matsushima Bay: pathological studies. Bull. Tohoku Reg. Fish. Res. Lab. 25, 89104.

Temperton, B., Thomas, S., Tait, K., Parry, H., Emery, M., Allen, M., et al., 2011. Permanent draft genome sequence of Vibrio tubiashii strain NCIMB 1337 (ATCC19106). Stand Genomic Sci. 4, 183-90.

Thompson, F. L., Gevers, D., Thompson, C. C., Dawyndt, P., Naser, S., Hoste, B., et al., 2005. Phylogeny and Molecular Identification of Vibrios on the Basis of Multilocus Sequence Analysis. Appl. Environ. Microbiol. 71, 5107-5115.

Thompson, F. L., Gómez-Gil, B., Ribeiro Vasconcelos, A. T., Sawabe, T., 2007. Multilocus Sequence Analysis reveals that Vibrio harveyi and V. campbellii are distinct species. Appl Environ Microbiol. 73, 4279-7285.

Thompson, F. L., Iida, T., Swings, J., 2004. Biodiversity of Vibrios. Microbiol. Mol. Biol. Rev. 68, 403-431.

Thompson, F. L., Li, Y., Gomez-Gil, B., Thompson, C. C., Hoste, B., Vandemeulebroecke, K., et al., 2003a. Vibrio neptunius sp. nov., Vibrio brasiliensis sp. nov. and Vibrio xuii sp. nov., isolated 
from the marine aquaculture environment (bivalves, fish, rotifers and shrimps). Int J Syst Evol Microbiol. 53, 245-52.

Thompson, F. L., Swings, J., Taxonomy of vibrios. In: F. L. Thompson, Austin, B., Swings, J., (Ed.), The Biology of Vibrios. ASM Press, Washington, DC, 2006, pp. 29-43.

Thompson, F. L., Thompson, C. C., Hoste, B., Vandemeulebroecke, K., Gullian, M., Swings, J., 2003b. Vibrio fortis sp. nov. and Vibrio hepatarius sp. nov., isolated from aquatic animals and the marine environment. Int J Syst Evol Microbiol. 53, 1495-1501.

Thompson, F. L., Thompson, C. C., Li, Y., Gomez-Gil, B., Vandenberghe, J., Hoste, B., et al., 2003c. Vibrio kanaloae sp. nov., Vibrio pomeroyi sp. nov. and Vibrio chagasii sp. nov., from sea water and marine animals. Int J Syst Evol Microbiol. 53, 753-9.

Thompson, F. L., Thompson, C. C., Swings, J., 2003d. Vibrio tasmaniensis sp. nov., isolated from Atlantic salmon (Salmo salar L.). Syst Appl Microbiol. 26, 65-9.

Tison, D. L., Seidler, R. J., 1983. Vibrio-aestuarianus - a New Species from Estuarine Waters and Shellfish. International Journal of Systematic Bacteriology. 33, 699-702.

Travers, M. A., Barbou, A., Le Goic, N., Huchette, S., Paillard, C., Koken, M., 2008. Construction of a stable GFP-tagged Vibrio harveyi strain for bacterial dynamics analysis of abalone infection. Fems Microbiology Letters. 289, 34-40.

Travers, M. A., Mersni Achour, R., Haffner, P., Tourbiez, D., Cassone, A. L., Morga, B., et al., 2014. First description of French $V$. tubiashii strains pathogenic to mollusk: I. Characterization of isolates and detection during mortality events. J Invertebr Pathol. 123, 38-48.

Travis, J., Potempa, J., Maeda, H., 1995. Are Bacterial Proteinases Pathogenic Factors. Trends in Microbiology. 3, 405-407.

Trinkler, N., Guichard, N., Labonne, M., Plasseraud, L., Paillard, C., Marin, F., 2011. Variability of shell repair in the Manila clam Ruditapes philippinarum affected by the Brown Ring Disease: A microstructural and biochemical study. Journal of Invertebrate Pathology. 106, 407-417.

Tubiash, H. S., Chanley, P. E., Leifson, E., 1965. Bacillary necrosis, a disease of larval and juvenile bivalve mollusks. I. Etiology and epizootiology. J Bacteriol. 90, 1036-44.

Tubiash, H. S., Colwell, R. R., Sakazaki, R., 1970. Marine vibrios associated with bacillary necrosis, a disease of larval and juvenile bivalve mollusks. J Bacteriol. 103, 271-2.

Vanhove, A. S., Duperthuy, M., Charriere, G. M., Le Roux, F., Goudenege, D., Gourbal, B., et al., 2014. Outer membrane vesicles are vehicles for the delivery of Vibrio tasmaniensis virulence factors to oyster immune cells. Environ Microbiol.

Vera-Cabera, L., Ortiz-Lopez , R., Elizondo-Gonzalez, R., Ocampo-Candiani, J., 2013. Complete genome sequence analysis of Nocardia brasiliensis HUJEG-1 reveals a saprobic lifestyle and genes needed for human pathognesis. PLoS One e65425.

Verschuere, L., Rombaut, G., Sorgeloos, P., Verstraete, W., 2000. Probiotic bacteria as biological control agents in aquaculture. Microbiol Mol Biol Rev. 64, 655-71.

Vezzulli, L., Brettar, I., Pezzati, E., Reid, P. C., Colwell, R. R., Hofle, M. G., et al., 2011. Long-term effects of ocean warming on the prokaryotic community: evidence from the vibrios. The ISME Journal. 1-10.

Vezzulli, L., Pezzati, E., Moreno, M., Fabiano, M., Pane, L., Pruzzo, C., 2009. Benthic ecology of Vibrio spp. and pathogenic Vibrio species in a coastal Mediterranean environment (La Spezia Gulf, Italy). Microbial Ecology. 58, 808-818.

Vezzulli, L., Previati, M., Pruzzo, C., Marchese, A., Bourne, D. G., Cerrano, C., 2010. Vibrio infections triggering mass mortality events in a warming Mediterranean Sea. Environ Microbiol. 12, 2007-19.

Villalba, A., Carballal, M. J., López, C., Cabada, A., Corral, L., Azevedo, C., 1999. Branchial rickettsia-like infection associated with clam Venerupis rhomboides mortality Diseases Of Aquatic Organisms. 36, 53-60.

Waechter, M., Le Roux, F., Nicolas, J. L., Marissal, E., Berthe, F., 2002. Characterisation of Crassostrea gigas spat pathogenic bacteria. Comptes Rendus Biologies. 325, 231-238.

Ward, J. R., Lafferty, K. D., 2004. The elusive baseline of marine disease: are diseases in ocean ecosystems increasing? PLoS Biol. 2, E120.

Wendling, C. C., Batista, F. M., Wegner, K. M., 2014. Persistence, seasonal dynamics and pathogenic potential of Vibrio communities from Pacific oyster hemolymph. Plos One. 9, e94256. 
Wilson, B., Muirhead, A., Bazanella, M., Huete-Stauffer, C., Vezzulli, L., Bourne, D. G., 2013. An improved detection and quantification method for the coral pathogen Vibrio coralliilyticus. Plos One. 8, e81800.

Wu, X., Li, D., Pan, J., Jaing, J., 2003. Studies on rickettsi like organism (RLO) disease of tropical marine pearl oyster- Epidemiological investigation of RLO disease in juvenile populations of maricultured Pincatda maxima. Acta Oceanol. Sin. 22, 421-435.

Wu, X., Pan, J., 1999. Studies on rickettsia-like organism disease of the tropical marine pearl oyster I: the fine structure and morphogenesis of pinctada maxima pathogen rickettsia-like organism. $J$ Invertebr Pathol. 73, 162-72.

Wu, X., Sun, J., Zhang, W., Wen, B., 2005. Purification and antigenic characteristics of a rickettsialike organism from the oyster Crassostrea ariakensis Dis Aquat Org. 67, 149-154.

Xu, J., Wang, Y., Xie, S. J., Xiao, J., Ruan, J. S., 2009. Streptomyces xiamenensis sp. nov., isolated from mangrove sediment. Int J Syst Evol Microbiol. 59, 472-6.

Zan, J., Liu, Y., Fuqua, C., Hill, R. T., 2014. Acyl-Homoserine Lactone Quorum Sensing in the Roseobacter Clade. . International Journal of Molecular Sciences. 15, 654-669.

Zhu, B., Wu, X., 2008. Identification of outer membrane protein ompR from rickettsia-like organism and induction of immune response in Crassostrea ariakensis. . Molecular Immunology. 45, 3198-3204.

Zhu, Z., Xu, T., He, Z., Wu, X., Wu, L., Meng, Q., et al., 2012. Rickettsia-like organism infection associated with mass mortalities of blood clam, Tegillarca granosa, in the Yueqing Bay in China. Acta Oceanol. Sin. 31, 106-115.

Zilber-Rosenberg, I., Rosenberg, E., 2008. Role of microorganisms in the evolution of animals and plants: the hologenome theory of evolution. FEMS Microbiol Rev. 32, 723-35. 
Table 1: Reviewed histopathological studies

\begin{tabular}{|c|c|c|c|c|c|c|}
\hline $\begin{array}{l}\text { Pathogenic species } \\
\text { detected / used }\end{array}$ & Host & Life stage & $\begin{array}{l}\text { Mortality outbreak / } \\
\text { experimental infection }\end{array}$ & Tissue & $\%$ Mortality & Reference \\
\hline $\begin{array}{l}\begin{array}{l}\text { Vibrio splendidus } \\
\text { biovar II }\end{array} \\
\text { V. alginolyticus }\end{array}$ & $\begin{array}{c}\text { Clam } \\
\text { V. decussatus }\end{array}$ & $\begin{array}{l}\text { Larvae and } \\
\text { spat }\end{array}$ & $\begin{array}{l}\text { Mortality outbreak in } \\
\text { hatchery and experimental } \\
\text { injection and immersion }\end{array}$ & $\begin{array}{l}\text { Velum and necrosis of tissues in larvae } \\
\text { Mantle, Disorganization of muscles } \\
\text { fibers and strong hemocytic infiltration } \\
\text { in the connective tissue }\end{array}$ & $\begin{array}{l}62 \% \text { recorded } \\
\text { during outbreak } \\
48 \text { to } 60 \% \text { in } 30 \\
\text { days } \\
\text { experimentally }\end{array}$ & Gomez-Leon et al., 2005 \\
\hline $\begin{array}{l}\text { Vibrio kanaloae / } \\
\text { V. pomeroyi }\end{array}$ & $\begin{array}{l}\text { Oyster } \\
\text { C. gigas }\end{array}$ & Adults & Experimental cohabitation & $\begin{array}{c}\text { Periphery of the muscle (lesions of the } \\
\text { translucent part of the adductor } \\
\text { muscle. }\end{array}$ & $15 \%$ in 8 days & Gay et al., 2004 \\
\hline $\begin{array}{l}\text { Vibrio splendidus- } \\
\text { related }\end{array}$ & $\begin{array}{l}\text { Scallop } \\
\text { P. maximus }\end{array}$ & Larvae & $\begin{array}{c}\text { Mortality outbreak in } \\
\text { hatchery }\end{array}$ & $\begin{array}{l}\text { Velar damage with necrosis and } \\
\text { detachment of velar cells }\end{array}$ & $100 \%$ in 3 to 5 days & Nicolas et al., 1996 \\
\hline V. tubiashii & $\begin{array}{c}\text { Oyster } \\
\text { C. gigas, O. edulis } \\
\text { Scallop } \\
\text { A. irradiens }\end{array}$ & Larvae & $\begin{array}{l}\text { Mortality outbreak in } \\
\text { hatchery }\end{array}$ & $\begin{array}{l}\text { Larval motility affected and increase in } \\
\text { soft-tissue necrosis }\end{array}$ & $100 \%$ in 12 hours & Tubiash et al., 1965 \\
\hline $\begin{array}{l}\text { V. coralliilyticus / } \\
\text { neptunius }\end{array}$ & $\begin{array}{c}\text { Mussel } \\
\text { P. canaliculus }\end{array}$ & Larvae & $\begin{array}{l}\text { Mortality outbreak in } \\
\text { hatchery }\end{array}$ & $\begin{array}{c}\text { Irregular movements, detachment of } \\
\text { cilia, aggregation of bacteria around } \\
\text { the velum and deterioration of soft } \\
\text { tissues }\end{array}$ & $75 \%$ in 7 days & $\begin{array}{l}\text { Kesarcodi-Watson et al., } \\
2009\end{array}$ \\
\hline V. tapetis & & Adults & Mortality outbreak & Colonize palleal cavity, periostracal & & Allam et al., 2002 \\
\hline
\end{tabular}




\begin{tabular}{|c|c|c|c|c|c|c|}
\hline & $\begin{array}{c}\text { Clam } \\
\text { V. philippinarum }\end{array}$ & & & $\begin{array}{l}\text { lamina, extrapalleal fluids, and } \\
\text { sometime internal circulatory system }\end{array}$ & & Paillard et al., 2004 \\
\hline $\begin{array}{l}\text { Roseovarius } \\
\text { crassostreae }\end{array}$ & $\begin{array}{l}\text { American oyster } \\
\text { Crassostrea } \\
\text { virginica }\end{array}$ & Juvenile & $\begin{array}{l}\text { Mortality outbreak at nursery } \\
\text { sites and experimental } \\
\text { injection and immersion }\end{array}$ & $\begin{array}{l}\text { Colonize inner surfaces of valves and } \\
\text { on deposited conchiolin } \\
\text { Mantle lesions, strong hemocytic } \\
\text { infiltration, epithelial degradation }\end{array}$ & $\begin{array}{l}\text { 95-100\% in 2-3 } \\
\text { weeks }\end{array}$ & $\begin{array}{l}\text { Ford \& Borrero, 2001, } \\
\text { Maloy et al., 2007b; } \\
\text { Boardman et al., 2008, } \\
\text { Gomez-Leon, et al., 2008 }\end{array}$ \\
\hline $\begin{array}{c}\text { Nocardia } \\
\text { crassostreae }\end{array}$ & $\begin{array}{l}\text { Pacific oyster } C \text {. } \\
\text { gigas }\end{array}$ & Adults & $\begin{array}{l}\text { Mortality outbreaks in mature } \\
\text { adults at field sites and } \\
\text { experimental injection studies }\end{array}$ & $\begin{array}{l}\text { Develop pustule-like, yellow to green } \\
\text { lesions in mantle, gills and adductor } \\
\text { muscle; colonies throughout } \\
\text { connective tissues, especially in } \\
\text { reproductive follicles and digestive } \\
\text { tissues } \\
\end{array}$ & $\begin{array}{l}\text { Up to } 47 \% \text { losses } \\
\text { within } 34 \text { days }\end{array}$ & $\begin{array}{c}\text { Friedman and Hedrick } \\
1991\end{array}$ \\
\hline \multirow[t]{6}{*}{ RLO } & $\begin{array}{l}\text { Oyster } \\
\text { C. rizophorae }\end{array}$ & Adults & Routine survey & $\begin{array}{l}\text { Intracytoplasmatic vacuoles in ciliated } \\
\text { gill filaments }\end{array}$ & & Azevedo et al 2005 \\
\hline & $\begin{array}{l}\text { Cockle } \\
\text { Cerastoderma } \\
\text { edule }\end{array}$ & Adults & Routine survey & $\begin{array}{l}\text { Rounded intracellular basophilic } \\
\text { colonies of rickettsiae- like organisms } \\
\text { were detected in epithelial cells of the } \\
\text { gills in digestive cells }\end{array}$ & $\begin{array}{l}13 \% \text { Prevalence in } \\
\text { gills and } 15 \% \\
\text { prevalence in } \\
\text { digestive system }\end{array}$ & Carballal et al 2001 \\
\hline & $\begin{array}{c}\text { Clam } \\
\text { Callista chione }\end{array}$ & Adults & $\begin{array}{l}\text { Mortality outbreak in } \\
\text { experimental hatchery system }\end{array}$ & $\begin{array}{c}\text { Rickettsialike colonies were detected } \\
\text { in the gills of all the individuals, with a } \\
\text { mean infection intensity of } 3 \\
\text { colonies/area and a mean colony size } \\
\text { of } 21.3 \mu \mathrm{m}\end{array}$ & $\begin{array}{l}70 \% \text { mortality in } 55 \\
\text { days }\end{array}$ & Delgado et al 2007 \\
\hline & $\begin{array}{l}\text { Oyster } \\
\text { Crassostrea } \\
\text { ariakensis }\end{array}$ & Adults & $\begin{array}{c}\text { Mortality recurrent annually } \\
\text { between february and may in } \\
\text { oyster farms }\end{array}$ & $\begin{array}{l}\text { large number of eosinophilic } \\
\text { intracytoplasmic inclusions in the } \\
\text { epithelial cells of the gills, digestive } \\
\text { gland, digestive tube and mantle. }\end{array}$ & $80-90 \%$ mortality & Wu and Pan 2000. \\
\hline & $\begin{array}{c}\text { Pearl oyster } \\
\text { Pinctada maxima }\end{array}$ & Juveniles & $\begin{array}{l}\text { Mortalities in culture } \\
\text { conditions }\end{array}$ & 87 \% infection in survivors. & $\begin{array}{l}\text { Up to } 70 \% \text { in } 2 \\
\text { months }\end{array}$ & Wu et al 2003 \\
\hline & $\begin{array}{c}\text { Cockle } \\
\text { Tegillarca granosa }\end{array}$ & & $\begin{array}{l}\text { Mortality occurred in at least } \\
5 \text { farms }\end{array}$ & $\begin{array}{l}\text { Intracytoplasmic inclusions within the } \\
\text { epithelial tissues of the mantle, gills } \\
\text { and digestive tube and within the } \\
\text { connective tissues of the mantle and }\end{array}$ & $\begin{array}{l}\text { mean mortality } \\
\text { rate }>10 \%\end{array}$ & Zhu et al 2012 \\
\hline
\end{tabular}




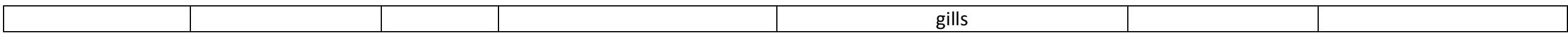



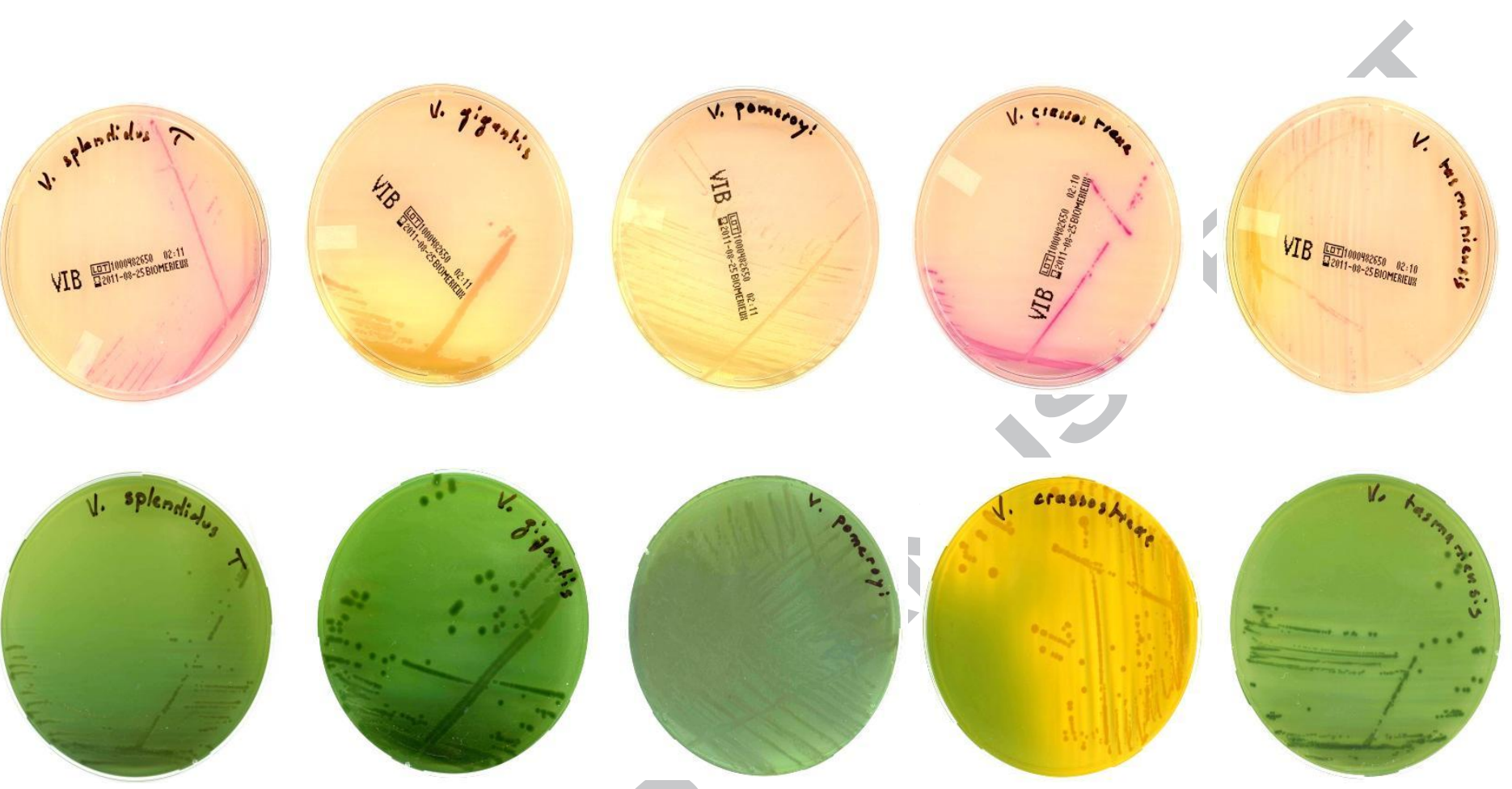

Figure 1: Phenotypic diversity on (A) ChromAgar and (B) TCBS, of strains belonging to the large Splendidus clade and particularly to $V$. splendidus, $V$. gigantis, $V$. pomeroyi, $V$. crassostreae, V. tasmaniensis species (P. Haffner)
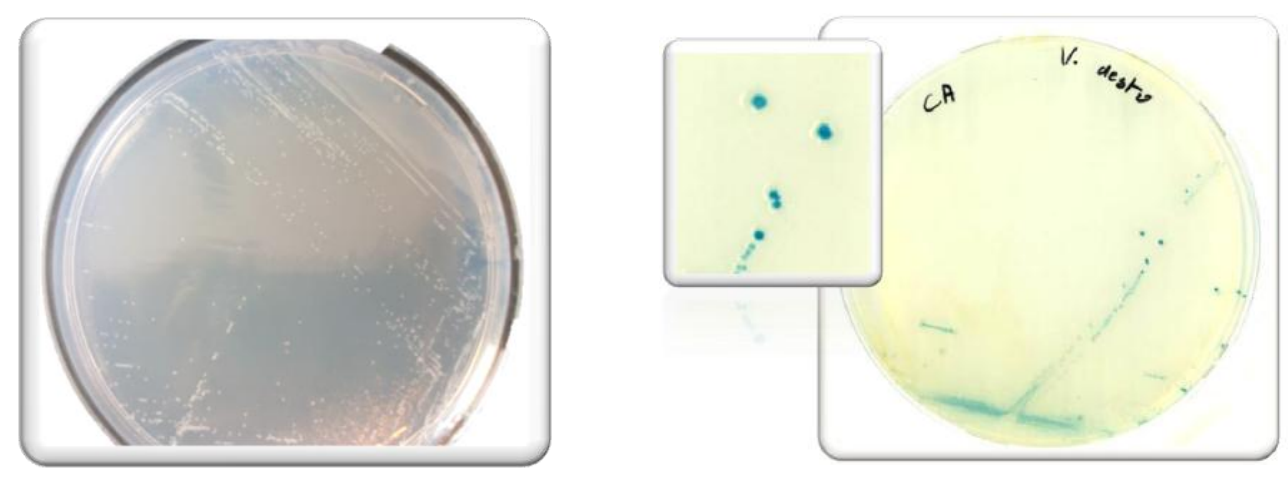
Figure 2: $V$. aestuarianus forms small colonies after $48 \mathrm{~h}$ at $22^{\circ} \mathrm{C}$ (A) on Zobell medium and (B) blue on ChromAgar.
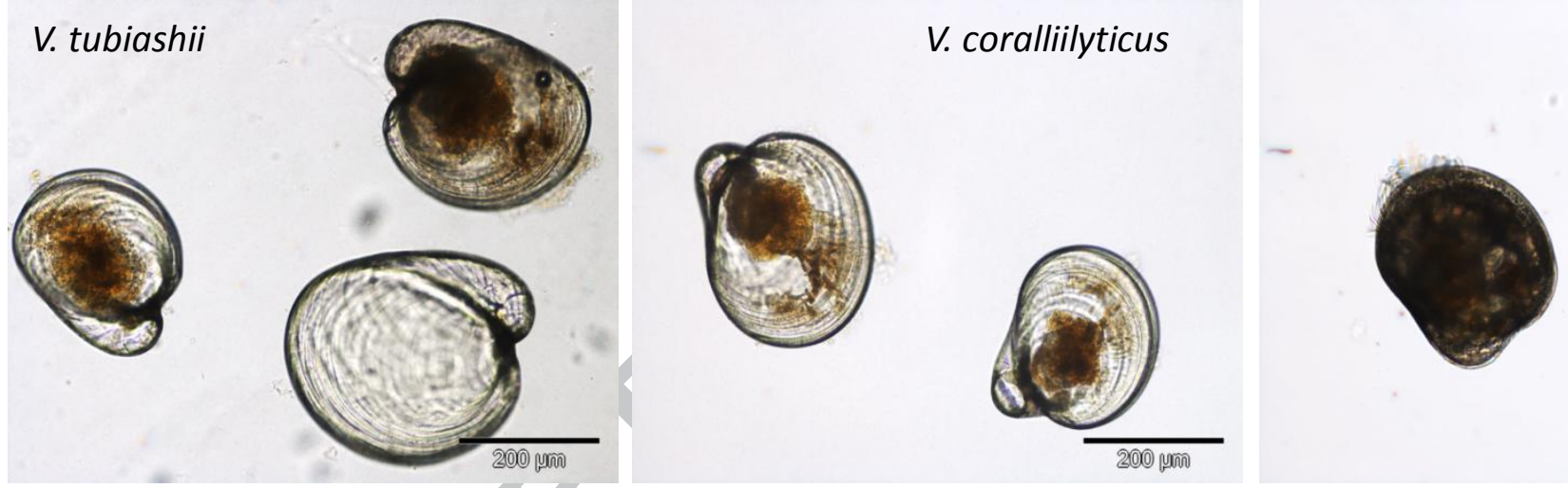

Figure 3: Detail of the non specific disease signs observed 24 hours post-infection in experimentally infected larvae with $V$. tubiashii (07/118 T2) or V. coralliilyticus (strain 06/210). Bar $=200 \mu \mathrm{m}$. 


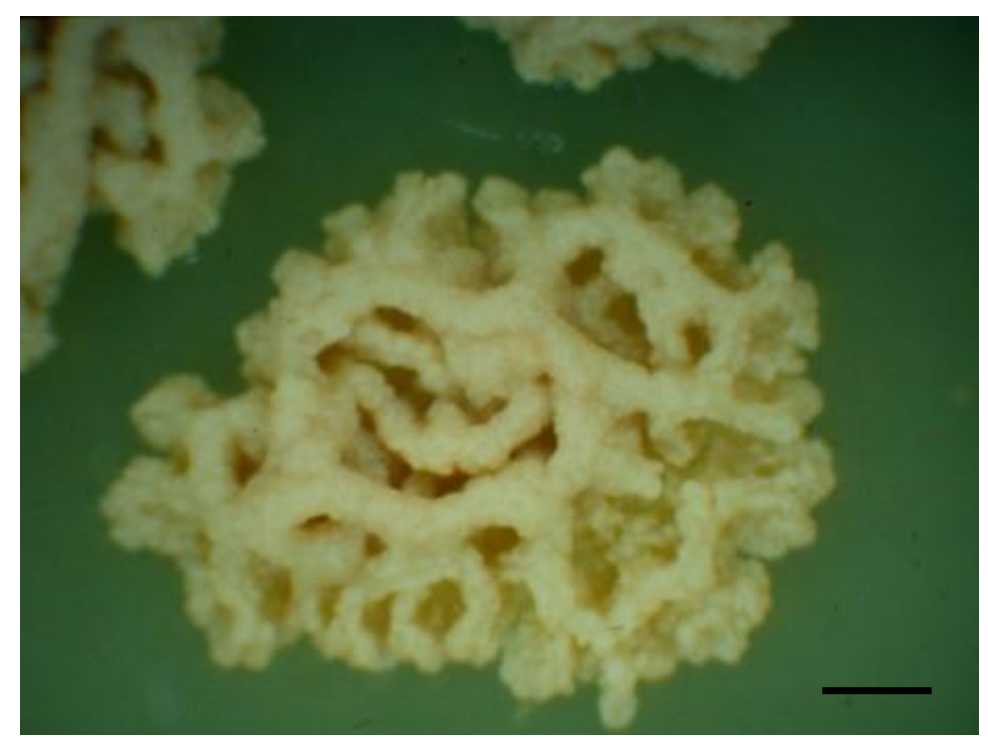

Figure 4. Colony of Nocardia crassostreae on Brain Heart Infusion agar. Bar $=10 \mu \mathrm{m}$.

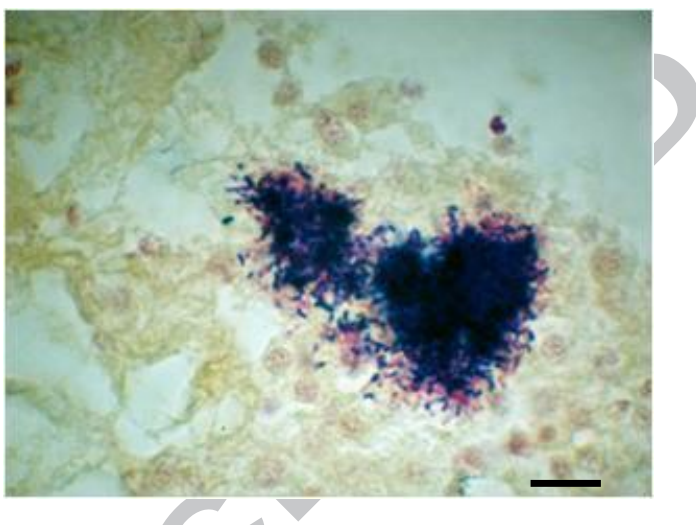

Figure 5. Gram-positive colonies of Nocardia crassostreae in connective tissues of a Pacific oyster. Brown and Brenn Gram stain. Bar $=10 \mu \mathrm{m}$. 

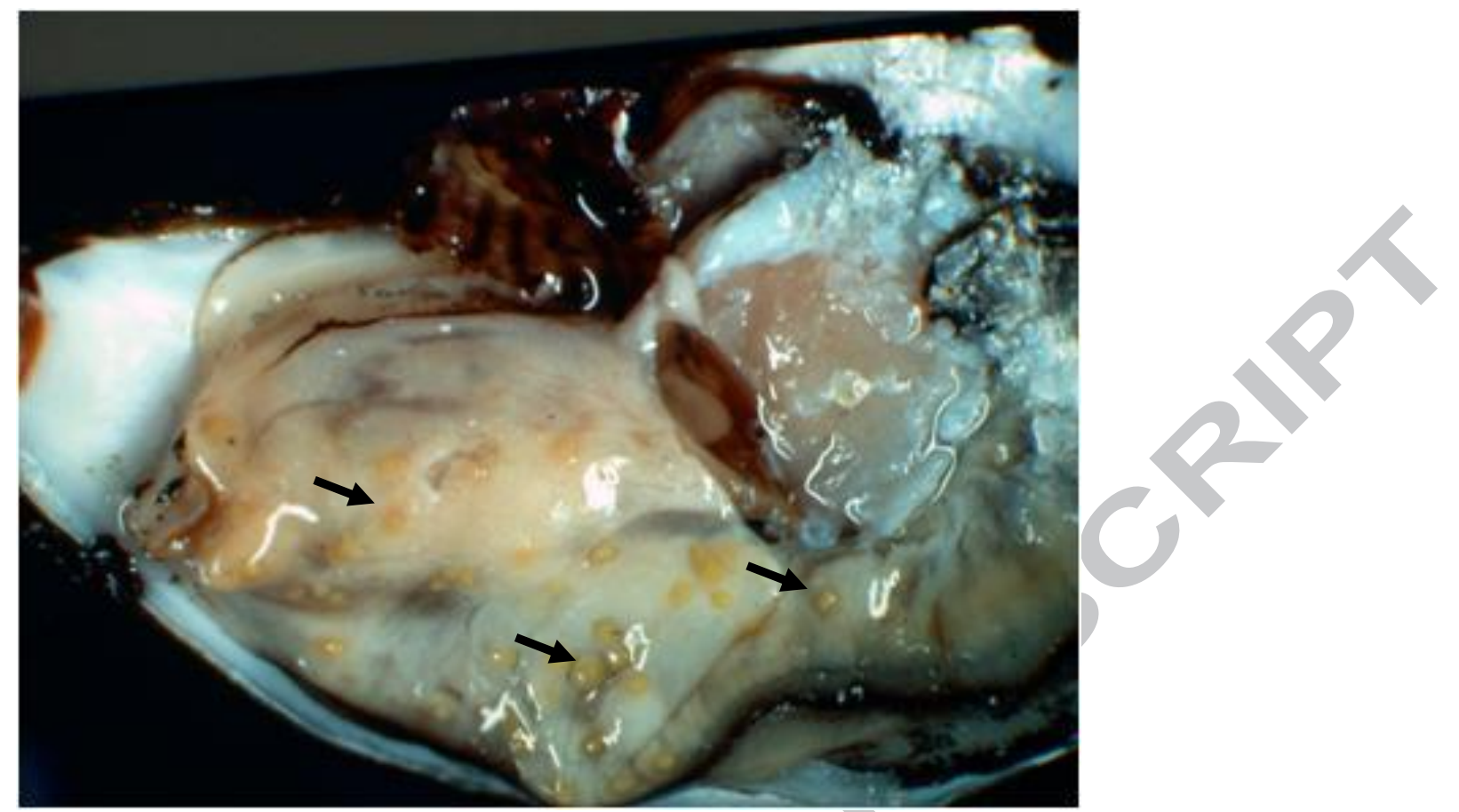

Figure 6. Pacific oyster with advanced nocardiosis as shown by the numerous pustule-like lesions throughout the mantle (arrows). Lesions are composed of $N$. crassostreae colonies and host hemocytes (Friedman et al; 1991). Reprint with permission.

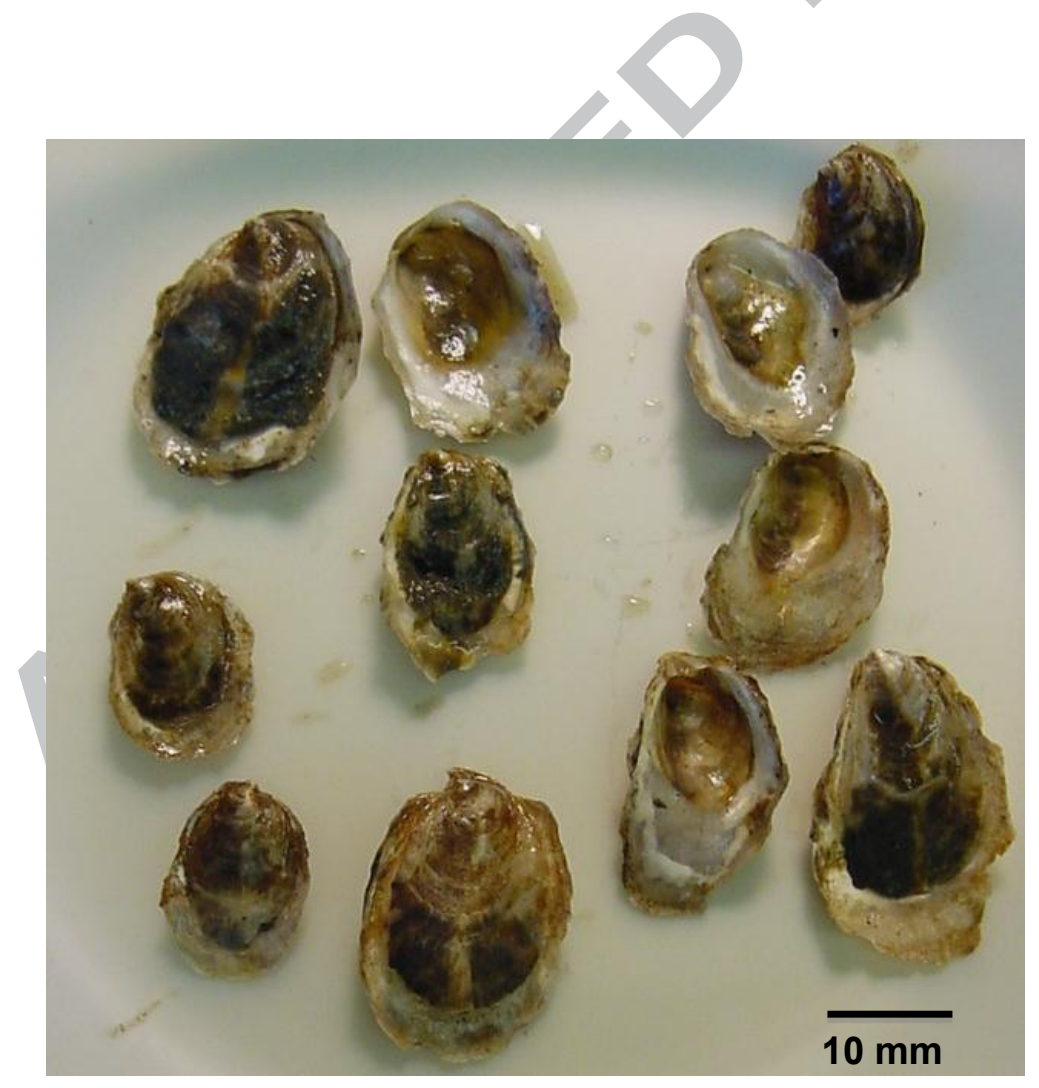


Figure 7. ROD-affected juvenile Crassostrea virginica exhibiting fragile, uneven valve margins and conchiolin deposits on inner valve surfaces. (A. Maloy)
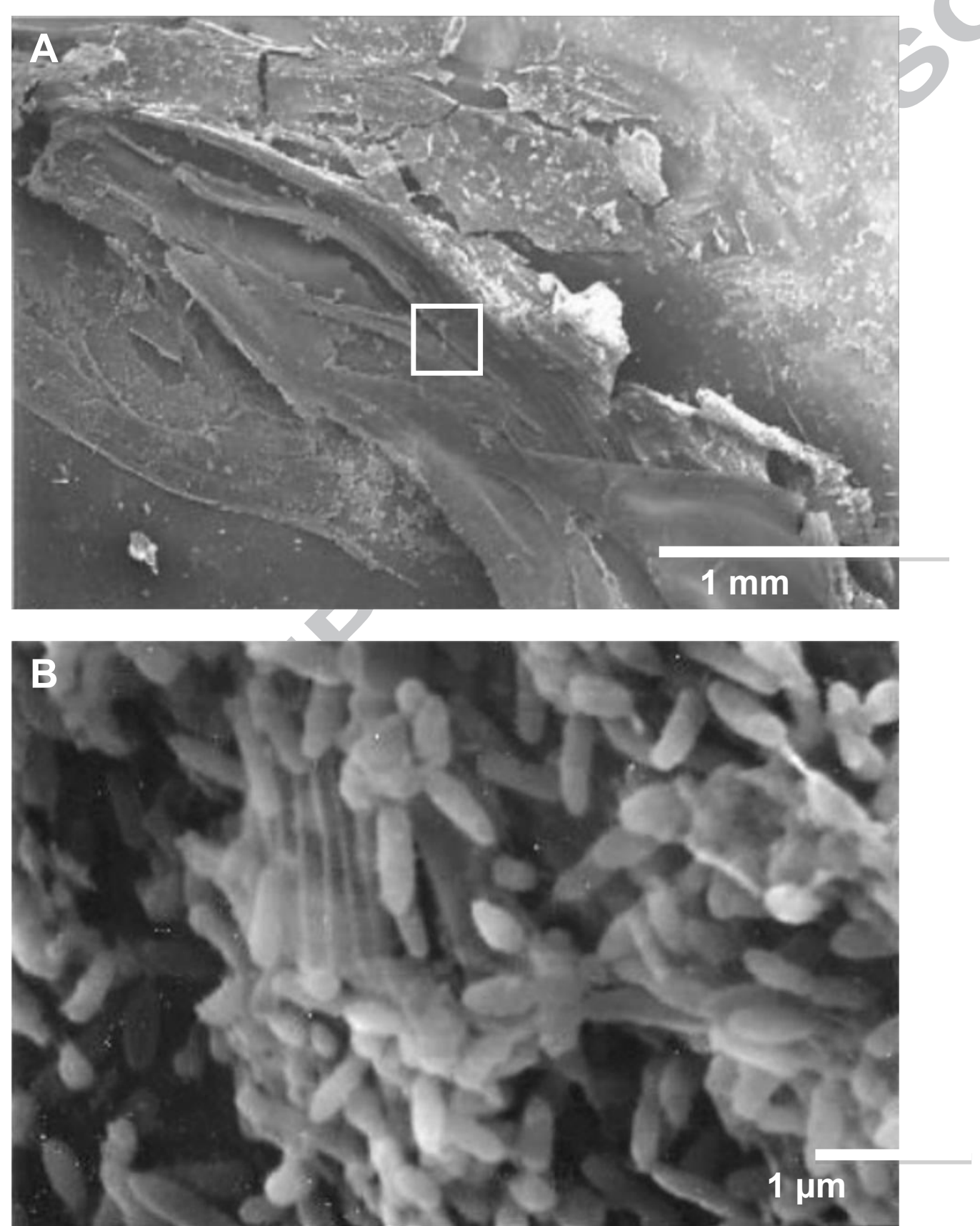

Figure 8: SEM images of an ROD-affected oyster. (A) Low magnification (30X) view of conchiolin deposit on inner shell valve. (B) High magnification (16000X) view of the boxed region of panel A revealing bacteria attached to the conchiolin surface. 
Table 2: Molecular diagnostic tools available

\begin{tabular}{|c|c|c|c|c|c|c|c|}
\hline $\begin{array}{l}\text { Pathogenic } \\
\text { species }\end{array}$ & Diagnostic tool & Application & Detected bacteria & Recommendations & $\begin{array}{l}\text { Number of tested } \\
\text { species/strains }\end{array}$ & Detection limit & Reference \\
\hline V. tasmaniensis & $\begin{array}{l}\text { PCR assay based on } \\
\text { 16s rDNA }\end{array}$ & Identification & $\begin{array}{c}\text { Various strains of } V \text {. } \\
\text { tasmaniensis } V . \text { splendidus and } \\
\text { other } V . \text { splendidus-related } \\
\text { species }\end{array}$ & $\begin{array}{l}\text { To combine with } \\
\text { biochemical assays for } \\
\text { discrimination }\end{array}$ & $\begin{array}{l}45 \text { species, } \\
62 \text { strains }\end{array}$ & $\begin{array}{c}500 \mathrm{fg} \text { of DNA } \\
2 \times 10^{2} \mathrm{CFU} / \mathrm{g} \text { of } \\
\text { infected clam }\end{array}$ & Lago et al., 2009 \\
\hline V. splendidus & $\begin{array}{l}\text { PCR assay based on } \\
\text { 16s rDNA }\end{array}$ & Identification & $\begin{array}{c}\text { Various strains of } V \text {. } \\
\text { tasmaniensis } V . \text { splendidus and } \\
\text { other } V . \text { splendidus-related } \\
\text { species }\end{array}$ & $\begin{array}{l}\text { To combine with } \\
\text { biochemical assays for } \\
\text { discrimination }\end{array}$ & $\begin{array}{l}45 \text { species, } \\
62 \text { strains }\end{array}$ & $\begin{array}{c}1 \mathrm{pg} \text { of DNA } \\
2 \times 10^{3} \mathrm{CFU} / \mathrm{g} \text { of } \\
\text { infected clam }\end{array}$ & Lago et al., 2009 \\
\hline V. neptunius & $\begin{array}{l}\text { PCR assay based on } \\
\text { 16s rDNA }\end{array}$ & Identification & $\begin{array}{l}\text { Various strains of } V . \text { neptunius } \\
\text { and } V \text {. parahaemolyticus }\end{array}$ & $\begin{array}{c}\text { To combine with } \\
\text { biochemical assays for } \\
\text { discrimination }\end{array}$ & $\begin{array}{l}45 \text { species, } \\
114 \text { strains }\end{array}$ & $1 \mathrm{pg}$ of DNA & Lago et al., 2009 \\
\hline \multirow[t]{2}{*}{ V. aestuarianus } & $\begin{array}{l}\text { QPCR assay based } \\
\text { on dnaJ }\end{array}$ & $\begin{array}{l}\text { Identification } \\
\text { Quantification }\end{array}$ & $\begin{array}{l}\text { All tested strains of } V . \\
\text { aestuarianus (10) }\end{array}$ & $\begin{array}{c}\text { Boiled isolates } \\
\text { Tissue/seawater DNA } \\
\text { extracts } \\
\end{array}$ & $\begin{array}{l}23 \text { species, } \\
34 \text { strains }\end{array}$ & $\begin{array}{c}1.6 \cdot 10^{2} \text { cells } / \mathrm{mg} \text { of } \\
\text { tissue }\end{array}$ & $\begin{array}{l}\text { Saulnier et al., } \\
2009\end{array}$ \\
\hline & $\begin{array}{c}\text { Colony blot } \\
\text { targeting gyrB }\end{array}$ & $\begin{array}{l}\text { Identification } \\
\text { Quantification }\end{array}$ & V. aestuarianus sp. & Cultivated bacteria & n.d. & n.d. & $\begin{array}{l}\text { Azandegbe et } \\
\text { al., } 2010\end{array}$ \\
\hline V. tubiashii & $\begin{array}{l}\text { QPCR assay based } \\
\text { on } g y r B\end{array}$ & $\begin{array}{l}\text { Identification } \\
\text { Quantification }\end{array}$ & $\begin{array}{l}\text { All tested strains of } V \text {. tubiashii } \\
\text { (10) }\end{array}$ & $\begin{array}{c}\text { Boiled isolates } \\
\text { Tissue/seawater DNA } \\
\text { extracts }\end{array}$ & $\begin{array}{l}9 \text { species } \\
21 \text { strains }\end{array}$ & $10^{2}$ bacteria $/ \mathrm{ml}$ & $\begin{array}{l}\text { Travers et al., } \\
2014\end{array}$ \\
\hline \multirow[t]{2}{*}{ V. coralliilyticus } & $\begin{array}{l}\text { QPCR assay based } \\
\text { on dnaJ }\end{array}$ & $\begin{array}{l}\text { Identification } \\
\text { Quantification }\end{array}$ & $\begin{array}{l}12 / 13 \text { strains of } V . \\
\text { coralliilyticus tested }\end{array}$ & & $\begin{array}{l}22 \text { species } \\
32 \text { strains }\end{array}$ & $\begin{array}{l}1 \mathrm{CFU} / \mathrm{ml} \text { in seawater } \\
10^{4} \mathrm{CFU} / \mathrm{cm}^{2} \text { of coral }\end{array}$ & $\begin{array}{c}\text { Pollock et al., } \\
2010 \\
\end{array}$ \\
\hline & $\begin{array}{l}\text { QPCR assay based } \\
\text { on } v c p A \\
\text { metalloprotease } \\
\end{array}$ & $\begin{array}{l}\text { Identification } \\
\text { Quantification }\end{array}$ & $\begin{array}{c}\text { Virulent strains of } V . \\
\text { coralliilyticus }(16)\end{array}$ & $\begin{array}{c}\text { Allow reclassification of } V \text {. } \\
\text { tubiashii RE22, ATCC19105 } \\
\text { and V. coralliilyticus C2 }\end{array}$ & $\begin{array}{l}18 \text { species } \\
34 \text { strains }\end{array}$ & 10 gene copies & $\begin{array}{l}\text { Wilson et al., } \\
2013\end{array}$ \\
\hline \multirow[t]{2}{*}{$\begin{array}{l}\text { V. tubiashii /V. } \\
\text { coralliilyticus }\end{array}$} & $\begin{array}{l}\text { PCR assay on } \\
\text { hemolysin ribA }\end{array}$ & Identification & $\begin{array}{c}\text { V. tubiashii strains (ATCC19109) } \\
\text { and V. coralliilyticus (RE22, } \\
\text { RE98, ATCC19105) }\end{array}$ & & $\begin{array}{l}10 \text { species } \\
23 \text { strains }\end{array}$ & n.d. & $\begin{array}{l}\text { Sathyamoorthy } \\
\text { et al., } 2011\end{array}$ \\
\hline & $\begin{array}{l}\text { QPCR assay based } \\
\text { on protease vtpA }\end{array}$ & $\begin{array}{l}\text { Identification } \\
\text { Quantification }\end{array}$ & $\begin{array}{l}\text { V. tubiashii strains (7) and } V \text {. } \\
\text { coralliilyticus (RE22, RE98, } \\
\text { ATCC19105) }\end{array}$ & $\begin{array}{l}\text { Environmental samples, } \\
\text { hatchery seawater, boiled }\end{array}$ & $\begin{array}{l}8 \text { species } \\
17 \text { strains }\end{array}$ & 10 bacteria & $\begin{array}{c}\text { Gharaibeh et } \\
\text { al., } 2009\end{array}$ \\
\hline
\end{tabular}




\begin{tabular}{|c|c|c|c|c|c|c|c|}
\hline & $\begin{array}{c}\text { Immunoassay } \\
\text { (directed against } \\
\text { metalloprotease } \\
\text { VtpA) }\end{array}$ & $\begin{array}{l}\text { Identification } \\
\text { Quantification }\end{array}$ & $\begin{array}{l}\text { V. coralliilyticus (RE22, RE98 } \\
\text { BAA450) }\end{array}$ & $\begin{array}{l}\text { Environmental samples, } \\
\text { hatchery seawater }\end{array}$ & $\begin{array}{l}4 \text { species } \\
5 \text { strains }\end{array}$ & $\begin{array}{l}0.5 \mu \mathrm{g} / \mathrm{ml} \text { of } \\
\text { protease }\end{array}$ & $\begin{array}{c}\text { Gharaibeh et } \\
\text { al., } 2013\end{array}$ \\
\hline \multirow[t]{7}{*}{ V. harveyi clade } & PCR on toxR gene & Identification & V. harveyi strains (10) & & $\begin{array}{l}8 \text { species } \\
18 \text { strains }\end{array}$ & n.d. & $\begin{array}{l}\text { Conejero and } \\
\text { Hedreyda, } 2003\end{array}$ \\
\hline & PCR on $16 s$ rRNA & Identification & $\begin{array}{l}\text { V. harveyi strains (24) and } \\
\text { V. alginolyticus strains }\end{array}$ & $\begin{array}{c}\text { To combine with } \\
\text { biochemical assays for } \\
\text { discrimination }\end{array}$ & $\begin{array}{l}9 \text { species } \\
44 \text { strains }\end{array}$ & n.d. & $\begin{array}{c}\text { Oakey et al., } \\
2003\end{array}$ \\
\hline & $\begin{array}{l}\text { AFLP, REP-PCR, } \\
\text { RAPD, RFLP }\end{array}$ & Diversity & $\begin{array}{l}\text { V. harveyi (15 environmental } \\
\text { strains) }\end{array}$ & $\begin{array}{c}\text { Type strains and samples } \\
\text { from farmed shrimp and } \\
\text { their water }\end{array}$ & $\begin{array}{l}14 \text { species } \\
29 \text { strains }\end{array}$ & n.d. & $\begin{array}{l}\text { Hernandez and } \\
\text { Olmos, } 2004\end{array}$ \\
\hline & RAPD & Diversity & V. harveyi strains (11) & $\begin{array}{c}\text { Isolated strains from } \\
\text { seabream, seabass, dentex }\end{array}$ & $\begin{array}{l}1 \text { species } \\
47 \text { strains }\end{array}$ & n.d. & $\begin{array}{l}\text { Pujalte et al., } \\
2003\end{array}$ \\
\hline & LAMP & Identification & V. harveyi strains (19) & $\begin{array}{c}\text { Diseased shellfish, aquatic } \\
\text { animals from different } \\
\text { sources }\end{array}$ & $\begin{array}{l}22 \text { species, } \\
44 \text { strains }\end{array}$ & $\begin{array}{l}17.2 \text { cells per } \\
\text { reaction }\end{array}$ & Cao et al., 2010 \\
\hline & TaqMan QPCR & $\begin{array}{l}\text { Identification } \\
\text { Quantification }\end{array}$ & $\begin{array}{c}V . \text { harveyi species } \\
\text { and virulent strains for abalone } \\
(10)\end{array}$ & $\begin{array}{c}\text { Boiled isolates } \\
\text { Tissue DNA extracts }\end{array}$ & $\begin{array}{l}7 \text { species } \\
17 \text { strains }\end{array}$ & $\begin{array}{l}1,8 \times 10^{\wedge} 1 \text { bacteria/ } \\
\text { reaction }\end{array}$ & $\begin{array}{c}\text { Schikorski et al } \\
2014\end{array}$ \\
\hline & ARDRA & Identification & Species & & $\begin{array}{l}14 \text { species } \\
15 \text { strains }\end{array}$ & n.d. & $\begin{array}{c}\text { Kita-Tsukamoto } \\
\text { et al } 2006 \\
\end{array}$ \\
\hline \multirow[t]{2}{*}{ V. tapetis } & $\begin{array}{l}\text { PCR assay on } 16 S \\
\text { rRNA }\end{array}$ & Identification & $\begin{array}{l}\text { V. tapetis strains ( } 23 \text { ) and some } \\
\text { cross-reaction } 3 \text { and } 6 \text { other } \\
\text { species for VtKF-VtKR and VtF- } \\
\text { VtR respectively }\end{array}$ & $\begin{array}{l}\text { Best specifidicty for Jvt1-Jvt2 } \\
\text { primers }\end{array}$ & $\begin{array}{l}29 \text { species } \\
51 \text { strains }\end{array}$ & 2-20 bacteria & $\begin{array}{l}\text { Paillard et al., } \\
\text { 2006; Park et } \\
\text { al., 2006; } \\
\text { Balboa et al., } \\
2011 \\
\end{array}$ \\
\hline & $\begin{array}{c}\text { ERIC-PCR, REP-PCR } \\
\text { and RAPD } \\
\end{array}$ & Diversity & V. tapetis strains (28) & & 28 strains & n.d. & $\begin{array}{c}\text { Rodriguez et al., } \\
2006\end{array}$ \\
\hline \multirow[t]{2}{*}{$\begin{array}{l}\text { Roseovarius } \\
\text { crassostreae }\end{array}$} & $\begin{array}{l}\text { PCR-RFLP of 16S- } \\
\text { 23S rDNA ITS }\end{array}$ & $\begin{array}{l}\text { Identification } \\
\text { and Diversity }\end{array}$ & Species and Genotype & $\begin{array}{l}\text { Most effective when inner } \\
\text { valve surfaces are sampled }\end{array}$ & $\begin{array}{l}6 \text { species } \\
506 \text { strains }\end{array}$ & $\begin{array}{c}10 \text { bacterial cells per } \\
\text { oyster }\end{array}$ & $\begin{array}{l}\text { Maloy et al., } \\
2005 ; 2007 a\end{array}$ \\
\hline & $\begin{array}{l}\text { Immunoassay } \\
\text { (polyclonal } \\
\text { antibody) }\end{array}$ & $\begin{array}{l}\text { Identification } \\
\text { and Localization }\end{array}$ & Species & $\begin{array}{l}\text { Can use in agglutination } \\
\text { assay, IFAT on swab smears } \\
\text { and/or tissue sections }\end{array}$ & 7 species & 1 bacterial cell & $\begin{array}{l}\text { Boardman, } \\
2005\end{array}$ \\
\hline $\begin{array}{l}\text { Nocardia } \\
\text { crassostreae }\end{array}$ & $\begin{array}{l}\text { PCR of } 16 S \text { rDNA } \\
\text { and qPCR of } 16 S-\end{array}$ & $\begin{array}{l}\text { Identification } \\
\text { and }\end{array}$ & Species & $\begin{array}{l}\text { Designed for use on oyster } \\
\text { tissues and bacterial }\end{array}$ & 16 strains & $\begin{array}{c}1300 \mathrm{cfu} / \mathrm{mL} \text { and } 13 \\
\mathrm{cfu} / \mathrm{mL}\end{array}$ & $\begin{array}{c}\text { Carrasco et al. } \\
2013\end{array}$ \\
\hline
\end{tabular}




\begin{tabular}{|l|l|l|l|l|l|l|}
\hline & 23S rDNA ITS & $\begin{array}{l}\text { Identification/ } \\
\text { Quantification }\end{array}$ & cultures & & \\
\hline
\end{tabular}

